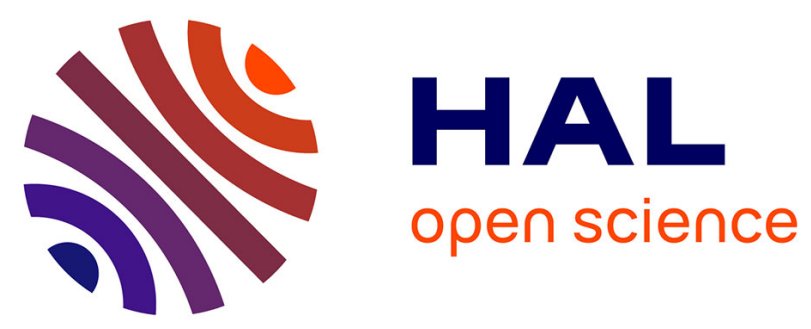

\title{
Under-Ice Phytoplankton Blooms in the Central Arctic Ocean: Insights From the First Biogeochemical IAOOS Platform Drift in 2017
}

Elisabeth Boles, Christine Provost, Veronique Garcon, Cécilia Bertosio, Marylou Athanase, Zoé Koenig, Nathalie Sennéchael

\section{To cite this version:}

Elisabeth Boles, Christine Provost, Veronique Garcon, Cécilia Bertosio, Marylou Athanase, et al.. Under-Ice Phytoplankton Blooms in the Central Arctic Ocean: Insights From the First Biogeochemical IAOOS Platform Drift in 2017. Journal of Geophysical Research. Oceans, 2020, 125 (3), pp.e2019JC015608. 10.1029/2019JC015608 . hal-03015239

\author{
HAL Id: hal-03015239 \\ https://hal.science/hal-03015239
}

Submitted on 19 Nov 2020

HAL is a multi-disciplinary open access archive for the deposit and dissemination of scientific research documents, whether they are published or not. The documents may come from teaching and research institutions in France or abroad, or from public or private research centers.
L'archive ouverte pluridisciplinaire HAL, est destinée au dépôt et à la diffusion de documents scientifiques de niveau recherche, publiés ou non, émanant des établissements d'enseignement et de recherche français ou étrangers, des laboratoires publics ou privés. 


\section{RESEARCH ARTICLE \\ 10.1029/2019JC015608 \\ Key Points: \\ - Two under-ice blooms were observed during an autonomous platform drift in the Western Eurasian Basin from April to December 2017 \\ - Unprecedentedly early spring bloom in Amundsen Basin consisted of potentially small, mixotrophic phytoplankton \\ - The summer bloom in Nansen Basin contained a greater diversity of planktonic size classes}

Supporting Information:

- Supporting Information S1

Correspondence to:

E. Boles,

elisalboles@gmail.com

Citation:

Boles, E., Provost, C., Garçon, V.,

Bertosio, C., Athanase, M., Koenig, Z., \& Sennéchael, N. (2020). Under-ice phytoplankton blooms in the Central Arctic Ocean: Insights from the first biogeochemical IAOOS platform drift in 2017. Journal of Geophysical

Research: Oceans, 125, e2019JC015608 https://doi.org/10.1029/2019JC015608

Received 9 SEP 2019

Accepted 27 FEB 2020

Accepted article online MAR 032020

(C)2020. American Geophysical Union. All Rights Reserved.

\section{Under-Ice Phytoplankton Blooms in the Central Arctic Ocean: Insights From the First Biogeochemical IAOOS Platform Drift in 2017}

\author{
Elisabeth Boles $^{1,2}$ iD, Christine Provost ${ }^{1}$ (D) Véronique Garçon $^{3}$ (D) Cécilia Bertosio ${ }^{1}$ iD, \\ Marylou Athanase $^{1}$ (D) Zoé Koenig $^{1,4}$ (D) and Nathalie Sennéchael ${ }^{1}$ \\ ${ }^{1}$ Laboratoire LOCEAN-IPSL, Sorbonne Université (UPMC, University Paris 6), CNRS, IRD MNHN, Paris, France, ${ }^{2}$ Now at \\ Environmental Fluid Mechanics Laboratory, Stanford University, Stanford, CA, USA, ${ }^{3}$ Laboratoire LEGOS (Etudes en \\ Géophysique et Océanographie Spatiales), (UPS, CNRS, IRD, CNES), Toulouse, France, ${ }^{4}$ Now at Geophysical Institute, \\ University of Bergen, Bergen, Norway
}

\begin{abstract}
In April 2017, the first Ice Atmosphere Arctic Ocean Observing System (IAOOS) platform equipped with biogeochemical sensors was deployed near the North Pole. Over the next 8 months it meandered southward with the ice, collecting measurements in the upper $250 \mathrm{~m}$ of Amundsen Basin, the Gakkel Ridge, Nansen Basin, and Fram Strait. Two distinct periods of primary production were encountered. The first bloom developed in the mixed layer in Amundsen Basin in May, reaching maximum chlorophyll $a$ concentrations on the order of $\sim 0.5 \mathrm{mg} \mathrm{m}^{-3}$ by the end of June. This bloom occurred earlier in the year than any other recorded bloom in Amundsen Basin, despite very limited under-ice light due to a thick layer of snow. The second bloom, encountered in Nansen Basin in August, was significantly larger (mean profile maximum chlorophyll $a$ was $1.45 \mathrm{mg} \mathrm{m}^{-3}$ ). Examinations of the optical community index and colored dissolved organic matter concentrations suggest that the spring bloom consisted of small phytoplankton which may have been mixotrophic, while the summer bloom contained a greater diversity of planktonic size classes. The data set demonstrates the heterogeneity of Arctic under-ice primary production, and is a valuable resource for validating coupled Earth System models.
\end{abstract}

Plain Language Summary Two IAOOS (Ice Atmosphere Arctic Ocean Observing System) autonomous platforms were deployed in 2017 and drifted with the ice through the Western Eurasian Basin, documenting physical and biogeochemical quantities in the upper ocean. The data reveal two phytoplankton blooms under the sea ice. The first occurred in May through June, before major ice melt began. It is likely that the organisms found here were mostly small and may have depended in part on alternative sources of energy to photosynthesis in order to survive in the low-light environment. The second bloom reached its peak in August and was able to grow much larger than the springtime bloom as it was well supplied with light and nutrients. This data set is an invaluable addition to our limited biological observations of the complex ecosystem under Arctic sea ice.

\section{Introduction}

The rapid warming of the Arctic region is expected to have profound impacts on Arctic ocean ecosystems. Arctic phytoplankton are primarily controlled by the extreme variations in the amount of light available for photosynthesis over the course of the year (Slagstad et al., 2015). As Arctic ice extent declines and multiyear ice is largely replaced by thinner, more translucent first-year ice (Perovich et al., 2018), primary production may be expanding both spatially and seasonally (Arrigo \& van Dijken, 2015; Assmy et al., 2017). Nutrient availability is also critical for Arctic primary production, and some studies suggest that nutrient concentrations will increase around the Eurasian Basin perimeter as a result of greater riverine discharge and reduced ice cover, which enhances wind-induced upwelling (Slagstad et al., 2015). However, greater ice melt may conversely strengthen stratification at the base of the mixed layer and limit the supply of nutrients to the surface (Bluhm et al., 2015). Because of the many complex feedbacks associated with ice cover as well as the logistical challenges of sampling under-ice biology, the ice zone is the region of greatest model uncertainty for Arctic primary production and biophysical interactions (Vancoppenolle et al., 2013). 
A number of under-ice blooms have been documented in recent years and provide stark evidence of the importance of primary production under ice (Arrigo et al., 2012; Assmy et al., 2017; Boetius et al., 2013; Mayot et al., 2018; Mundy et al., 2009, 2014; Strass \& Nöthig, 1996). For example, Arrigo et al. (2012, 2014) estimated that under-ice blooms contribute $90 \%$ to total primary production in the Chukchi Sea. However, most sampling has been performed near the ice edge or during summer months, neglecting a significant portion of the year and region of the central Arctic. Additionally, most models employ only remote sensing data to validate Arctic primary production, assuming under-ice biomass to be negligible. There is a clear and urgent need to expand measurements both spatially and temporally in order to improve our understanding of the heterogeneity in phytoplankton communities and of the annual cycle of primary production.

Autonomous platforms equipped with biogeochemical sensors have the potential to supply the high-resolution, long-term measurements required to investigate these questions (Berge et al., 2016). To date, eight ice-tethered profilers (ITPs) measuring biogeochemical parameters (optical backscattering, photosynthetically active radiation, chlorophyll $a$, and colored dissolved organic matter) have been deployed, four within the Canadian Basin and four within the transpolar drift (Laney et al., 2014, 2017). Additionally, one study was performed with a buoy deployed in seasonal ice cover near the Chukchi shelf that was equipped with biogeochemical sensors at fixed depths (Hill et al., 2018). Biogeochemical Argo floats were also recently employed for a study in the Greenland Sea seasonal ice zone (Mayot et al., 2018).

The Ice Atmosphere Arctic Ocean Observing System (IAOOS) project deployed its first platform equipped with biogeochemical sensors in 2017. In addition to the parameters measured by ITPs, the IAOOS platform also documented nitrate concentrations as well as snow, ice, and atmospheric conditions along the drift. Athanase et al. (2019) used data from this profiler to describe the hydrographic characteristics of the upper layer of the Eurasian Basin in 2017. This subsequent paper examines the phytoplankton blooms observed along the drift with regard to ice cover, light, and hydrography, to understand the environmental factors that control the development of under-ice blooms in the central Arctic and their community composition.

The paper is organized as follows. Section 2 describes the platform drift, instrumentation, and data processing. Section 3 presents the results, providing an overview of seasonal changes in ice cover, snow, and light availability during the drift and descriptions of the two blooms. Discussions of biological community composition and the factors governing under-ice productivity in the Central Arctic are found in section 4. Section 5 highlights the major findings and puts the work into perspective.

\section{Data and Methods}

\subsection{Platform Drift and Instrumentation}

Two IAOOS platforms (IAOOS 23 and IAOOS 24) were deployed on 12 April 2017 from the Russian-operated, Barneo ice camp near the North Pole (starting location for IAOOS 23: $89.1576^{\circ} \mathrm{N}$, $28.0356^{\circ} \mathrm{E}$; IAOOS $24: 89.1513^{\circ} \mathrm{N}, 27.2874^{\circ} \mathrm{E}$ ). These platforms drifted with the ice pack, documenting simultaneous atmospheric and oceanic conditions along their trajectories. Remaining within $3 \mathrm{~km}$ of each other, the platforms drifted south within Amundsen Basin, across the Gakkel Ridge, then within Nansen Basin before exiting the Arctic through Fram Strait (Figure 1a).

A summary of both platforms' instrumentation, acquired data, and measurement precisions is presented in Table 1. IAOOS 24 was a standard platform, equipped with a weather mast and microlidar (Mariage et al., 2017), an ice mass balance instrument (Jackson et al., 2013), and an ocean profiler (Koenig et al., 2016). The SAMS (Scottish Association for Marine Science) Ice Mass Balance for the Arctic (hereafter SIMBA) instrument recorded temperature profiles and a proxy for thermal resistivity along a 5-m chain cable that passed through the air, snow, ice, and surface ocean. The ocean profilers were PROVOR SPI (from French manufacturer NKE), which included a Seabird SBE41 CTD (conductivity, temperature, depth) and a dissolved oxygen (DO) Aandera 4330 optode.

The IAOOS 23 profiler was also equipped with a suite of biogeochemical sensors (Figure 1b). These consisted of a submersible, chemical free, ultraviolet nitrate analyzer (SUNA, Satlantic-Seabird Inc.) and a Pack Rem A bio-optics suite, combining a three-optical-sensor instrument (ECO Triplet, WET Labs Inc.) and a multispectral radiometer (OCR-504, Satlantic Inc.). The ECO Triplet measured chlorophyll $a$ fluorescence (Chl $a$, 

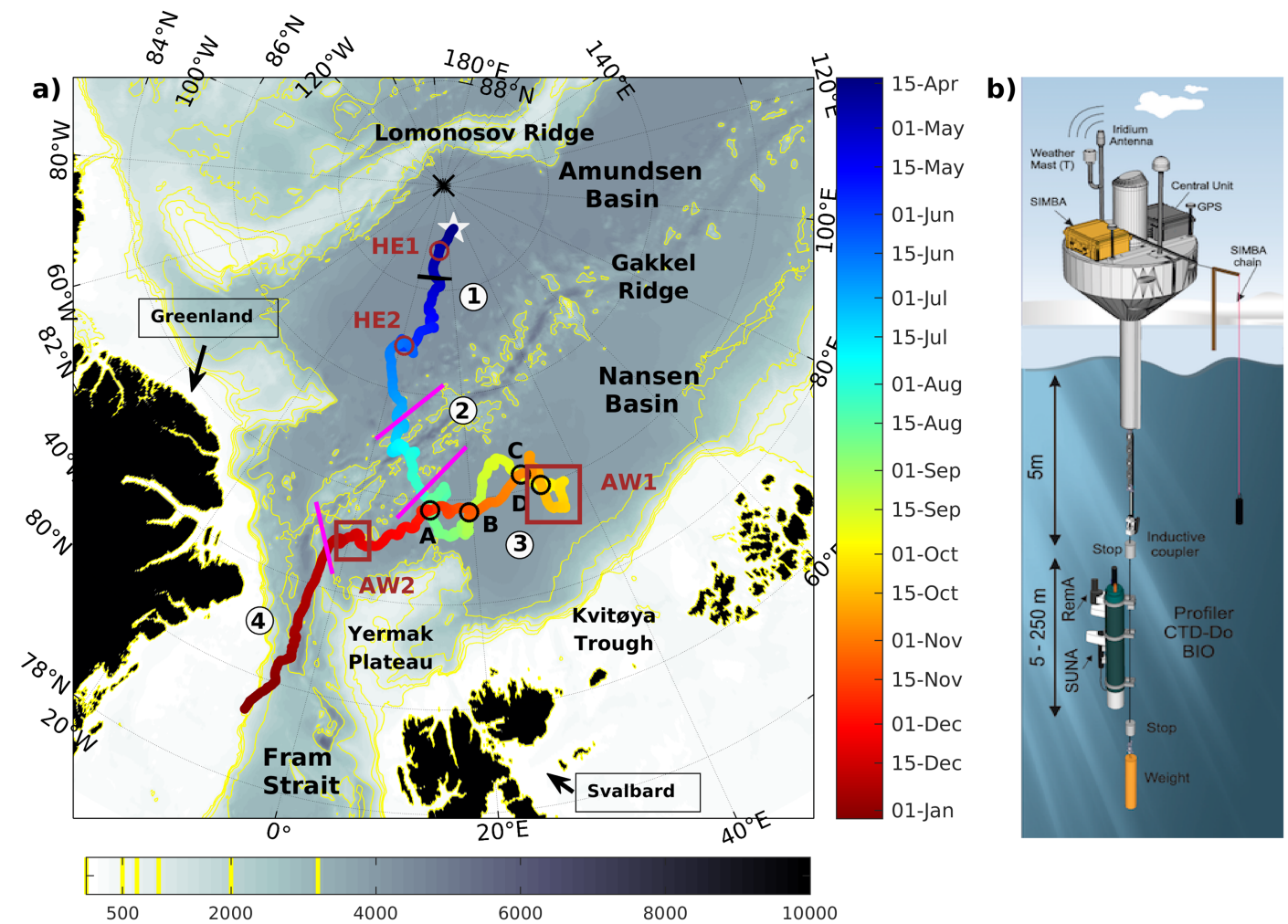

Figure 1. (a) Drift trajectory of the IAOOS platforms from 12 April 2017 to 4 January 2018. Color code is time, bathymetry (IBCAO) is in grayscale with yellow isolines at 500, 1,000, 2,000, and 3,300 m. Magenta lines delineate the four regions, which are also indicated by circled numbers: (1) Amundsen Basin, (2) Gakkel ridge, (3) Nansen Basin, and (4) the western Fram Strait and Greenland continental slope. The black line at $88.2^{\circ} \mathrm{N}$ indicates the frontal zone. Black circles mark four major crossing points (A, B, C and D). Brown circles indicate the location of two halocline eddies (HE1 and HE2) and brown squares indicate the locations of two Atlantic water masses (AW1 and AW2). (b) Schematic of IAOOS 23, equipped with IMB chain, CTD-DO sensors, bio-optics sensor suite (RemA) and nitrate sensor (SUNA).

excitation at $470 \mathrm{~nm}$, emission at $695 \mathrm{~nm})$, backscatter $\left(b_{\mathrm{bp}}\right.$, emission at $\left.700 \mathrm{~nm}\right)$, and colored dissolved organic matter fluorescence (CDOM, excitation at $370 \mathrm{~nm}$, emission at $460 \mathrm{~nm}$ ). The OCR radiometer measured downwelling irradiances at 412, 490, and $555 \mathrm{~nm}$ in addition to photosynthetically active radiation (PAR, range 400-700 $\mathrm{nm}$ ). Irradiance measurements were not employed in this study.

The platforms were programmed to perform two upward profiles each day, from $250 \mathrm{~m}$ (IAOOS 23) to $350 \mathrm{~m}$ (IAOOS 24) beginning at approximately 6 a.m. and 6 p.m. UTC. From July onward, profiler data in the surface mixed layer are frequently missing. The profilers were prevented from fully completing their ascents, either due to strong stratification at the pycnocline or rapid platform displacement. There were also two instrument outages that affected both platforms and lasted several days-one from 19 to 26 August and one from 17 to 22 September (Athanase et al., 2019).

Additionally, a webcam mounted above the ice on IAOOS 24 recorded images 4 times a day, providing qualitative snapshots of meteorology and the state of the ice surface over the course of the drift. Ice coverage data were obtained from MODIS satellite imagery with $3.125 \mathrm{~km}$ resolution at this site (ftp://ftp-projects.cen.uni-hamburg.de/seaice/AMSR $2 / 3.125 \mathrm{~km} /$ ).

\subsection{Data Corrections and Additional Calculations}

Remarkably little instrumental drift occurred over the 8-month period (see supporting information for further analysis). The exception to this was nitrate measurements, which deviate by $1.5 \mu \mathrm{mol} \mathrm{kg}^{-1}$ from baseline over the whole water column beginning in November and return to baseline in December in Fram Strait (Figures S1, S2a, and S2b). Because of the displacement of the buoy, it is difficult to determine whether these values are real or are caused by instrument drift, and nitrate values from November 


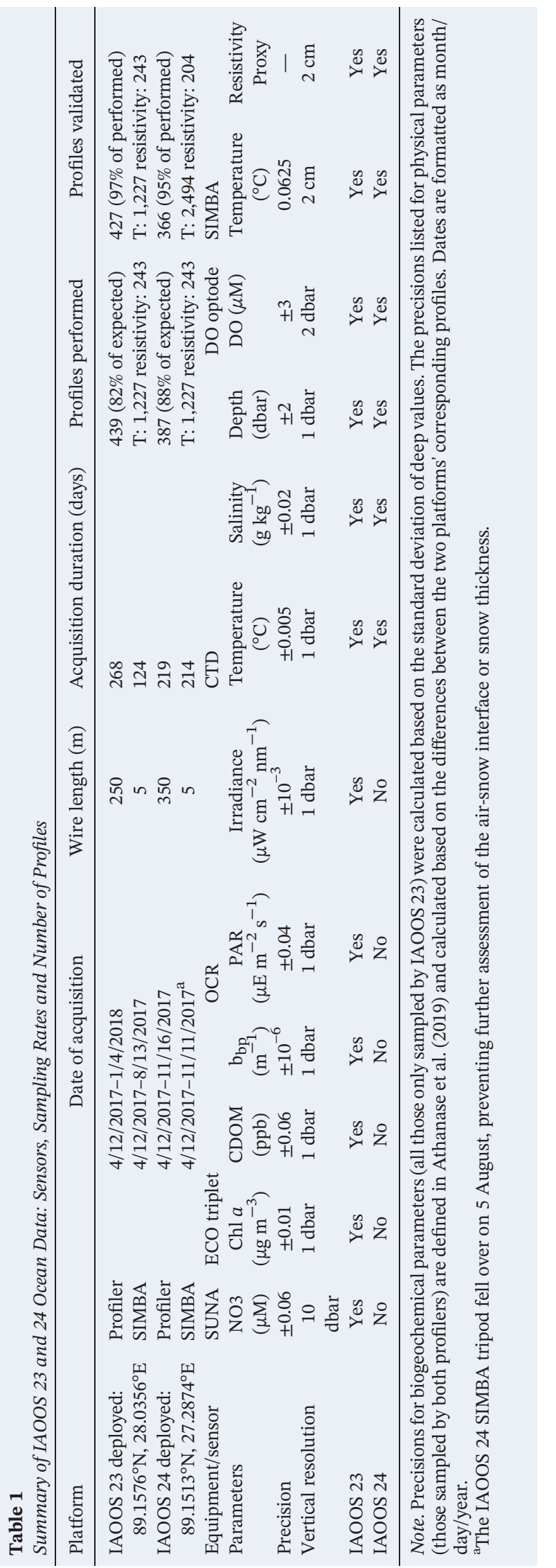

onward should be treated with caution. Backscatter also increased suddenly along the length of the profile in mid-November, but values at depth subsequently returned to baseline (Figures S1 and S2a).

Temperature, salinity, and oxygen measurements from the two platforms were averaged for each corresponding profile, as in Athanase et al. (2019). Calculations and corrections of absolute salinity (SA), conservative temperature (CT), apparent oxygen utilization (AOU), and nitrate $\left(\mathrm{NO}_{3}\right)$ are also described in Athanase et al. (2019).

The remaining biogeochemical parameters ( $b_{\mathrm{bp}}$, Chl $a$, CDOM, and PAR) were converted from raw counts and corrected for offsets determined during factory calibrations (see supporting information). Next, a vertical shift was applied to Chl $a$ and PAR values in order to set "dark values" to zero. This was achieved by first calculating a depth-averaged dark value from $200-250 \mathrm{~m}$ for each profile, then applying linear fits to these dark values over three sections of time (before, between, and after the two major instrument outages) and subtracting these fits from all measurements. The linear fit was chosen in order to correct for any long-term drift in the sensor. These shifts resulted in changes to PAR values from -0.008 to $0.029 \mu \mathrm{E} \mathrm{m}^{-2} \mathrm{~s}^{-1}$ and changes to Chl $a$ values from -0.056 to $-0.060 \mathrm{mg} \mathrm{m}^{-3}$. The magnitudes of these changes are quite small compared to the measurements and help validate the integrity of the data set. As concentrations of CDOM and backscatter could realistically be nonzero at depth, a shift was not applied to these time series. Due to large environmental variability in phytoplankton photophysiology, spectral properties of CDOM, and suspended particulate size and composition across the Arctic, it was deemed impractical to more accurately refine $\mathrm{Chl} a, \mathrm{CDOM}$, and $b_{\mathrm{bp}}$ estimates. All data were vertically interpolated to $0.5 \mathrm{dbar}$ of resolution. The upper $100 \mathrm{~m}$ of the profiles along the drift are presented in Figure 2. Data analyzed in this publication can be found in Provost et al. (2017).

\subsubsection{Daylight}

Hours of daylight along the platform drift were calculated using the formula for the hour angle at sunrise/sunset then converted to hours

$$
t_{\text {daylight }}=\cos ^{-1}(-\tan (\Phi) * \tan (\delta)) * \frac{24}{360} * 2,
$$

where $\delta$ is the solar declination

$$
\delta=23.5 * \sin \frac{t}{365} * 360,
$$

$\Phi$ is latitude, and $t$ is days since the vernal equinox (21 March). The maximum daily solar elevation is similarly calculated as

$$
\alpha_{s}=\sin ^{-1}(\sin (\Phi) * \sin (\delta)+\cos (\Phi) * \cos (\delta))
$$

and set to 0 for all negative $\alpha_{s}$.

\subsubsection{PAR Near the Surface}

The upper limit of PAR values varied along the drift. However, approximate values for PAR directly beneath the surface were calculated by fitting each PAR profile to the canonical natural log shape

$$
\operatorname{PAR}(z)=A^{*} \exp \left(-B^{*} z\right),
$$

where $A$ and $B$ were fitting parameters chosen separately for each profile (e.g., Laney et al., 2017; Massicotte et al., 2018). Only PAR profiles with upper 
measurements exceeding $0.6 \mu \mathrm{E} \mathrm{m}^{-2} \mathrm{~s}^{-1}$ were fitted, and only fitted profiles calculated from equation (4) that have RMSE $<0.15$ compared to the data were kept for the analysis. Overall, the temporal variations in the calculated PAR at $2 \mathrm{~m}$ match well with those from observations at $30 \mathrm{~m}$, except in early July when the fitted profile predicts a drop in PAR at $2 \mathrm{~m}$ that is not observed at $30 \mathrm{~m}$. The mismatch is expected to be a result of missing near-surface PAR measurements during this period.

\subsubsection{Optical Community Index}

The optical community index (OCI) was calculated as the ratio of chlorophyll $a$ fluorescence to backscatter (Chl $a / b_{\text {bp }}$ ). While few studies including optical community indices have been published, evidence suggests the ratio can provide an indication of the community composition of phytoplankton blooms (Cetinić et al., 2015; Nencioli et al., 2010). For example, by comparing optical in situ and ship-based measurements in the Icelandic Basin, Cetinić et al. (2015) found that the OCI during a spring diatom bloom was twice as large as that during a subsequent picophytoplankton and nanophytoplankton dominated bloom.

\section{Results}

\subsection{Snow, Ice, and Light Conditions Along the Drift}

The Sun remained above the horizon from April through August, providing $24 \mathrm{hr}$ of daylight, and the maximum solar elevation was reached on 1 July (Figure 3a). Daylight hours rapidly decreased in September to zero from October through the end of the drift. At the beginning of the drift, atmospheric temperatures fluctuated around $-20{ }^{\circ} \mathrm{C}$, and at IAOOS 23 snow cover was $0.22 \mathrm{~m}$ and ice cover was $1.52 \mathrm{~m}$ thick (Figures $3 \mathrm{~b}$ and 3c). Despite $24 \mathrm{hr}$ of daylight, under-ice PAR was low during the first 2 months (increasing from 0.25 to $2.5 \mu \mathrm{E} \mathrm{m}^{-2} \mathrm{~s}^{-1}$ at $5 \mathrm{~m}$ ) indicative of nearly complete ice cover and thick snow (Figures 3c-3e).

Air temperatures reached $0^{\circ} \mathrm{C}$ by 15 June, initiating a melting of surface snow cover and increasing under-ice $\operatorname{PAR}\left(>20 \mu \mathrm{E} \mathrm{m}^{-2} \mathrm{~s}^{-1}\right.$ at $5 \mathrm{~m}$ at the end of June). By mid-July hardly any snow remained, and on 20 July large swaths of the surface were covered in melt ponds (Figure 3f). Basal ice melt also began in July; ice thickness decreased from 1.8 to $1.4 \mathrm{~m}$ over the month (Figure 3c). Under-ice light levels reached some of their greatest values during this time ( $\mathrm{PAR}>7.5 \mu \mathrm{E} \mathrm{m}^{-2} \mathrm{~s}^{-1}$ at $30 \mathrm{~m}$ on 25 and $27 \mathrm{July}$ ). The extensive melt ponds visible at the end of July were largely drained out by early August, leaving the surface scattered with smaller, isolated ponds (Figure 3g); during this time under-ice PAR decreased by about one third. Many peaks in PAR between July and September correspond well with sudden drops in ice cover percentage, suggesting that lead openings also likely caused abrupt increases in under-ice light (Figures $3 \mathrm{~d}$ and $3 \mathrm{e}$ )). The webcam photos support this assumption, showing the presence of a nearby lead perhaps as early as May and clearly visible from August (Figure 3g) through September. Changes in cloud cover are also expected to contribute to minor day-to-day fluctuations in PAR. PAR exhibited a sudden all-time maximum on 6 August (PAR $=13.0 \mu \mathrm{E}$ $\mathrm{m}^{-2} \mathrm{~s}^{-1}$ at $30 \mathrm{~m}$ ), aligning with a minimum in ice cover.

Under-ice light levels remained high until mid-September, when local ice cover returned to nearly $100 \%$ (PAR $~ 3.65 \pm 2.16 \mu \mathrm{E} \mathrm{m}^{-2} \mathrm{~s}^{-1}$ at $30 \mathrm{~m}$ ) and daylight hours diminished rapidly.

\subsection{Under-Ice Phytoplankton Blooms}

\subsubsection{Spring Bloom in Amundsen Basin}

The first significant under-ice Chl $a$ concentrations were observed in Amundsen Basin during the months of May and June, a period which will henceforth be referred to as the spring bloom. Profiles during this bloom are presented in Figure 4.

The surface mixed layer was comparatively deep during the springtime drift in Amundsen Basin, with a well-defined top of the pycnocline at $\sim 50 \mathrm{~m}$ until mid-June (see white density isolines in Figure 2). The mixed layer exhibited low AOU $\left(-5-5 \mu \mathrm{mol} \mathrm{kg}{ }^{-1}\right)$ and was depleted in nitrate $\left(0-2 \mu \mathrm{mol} \mathrm{kg}^{-1}\right)$ (Figures 2d and 2e). The upper $100 \mathrm{~m}$ were also heavily enriched in CDOM (3-5 ppb, Figure 2f).

Measurements of Chl $a$ concentrations above $30 \mathrm{~m}$ were consistently greater than $0.15 \mathrm{mg} \mathrm{m}^{-3}$ by 1 May, and elevated values extended to the depth of the mixed layer $(\sim 50 \mathrm{~m})$ by 10 May (Figures $2 \mathrm{~g}$ and $4 \mathrm{a}$ ). While these values are not large, they are noticeably greater than dark values and suggest an increase in biological activity. This bloom subsequently remained confined to the mixed layer, where Chl $a$ concentrations gradually increased through June (the average of the Chl $a$ profile maximums was $0.5 \mathrm{mg} \mathrm{m}^{-3}$ in late June, 


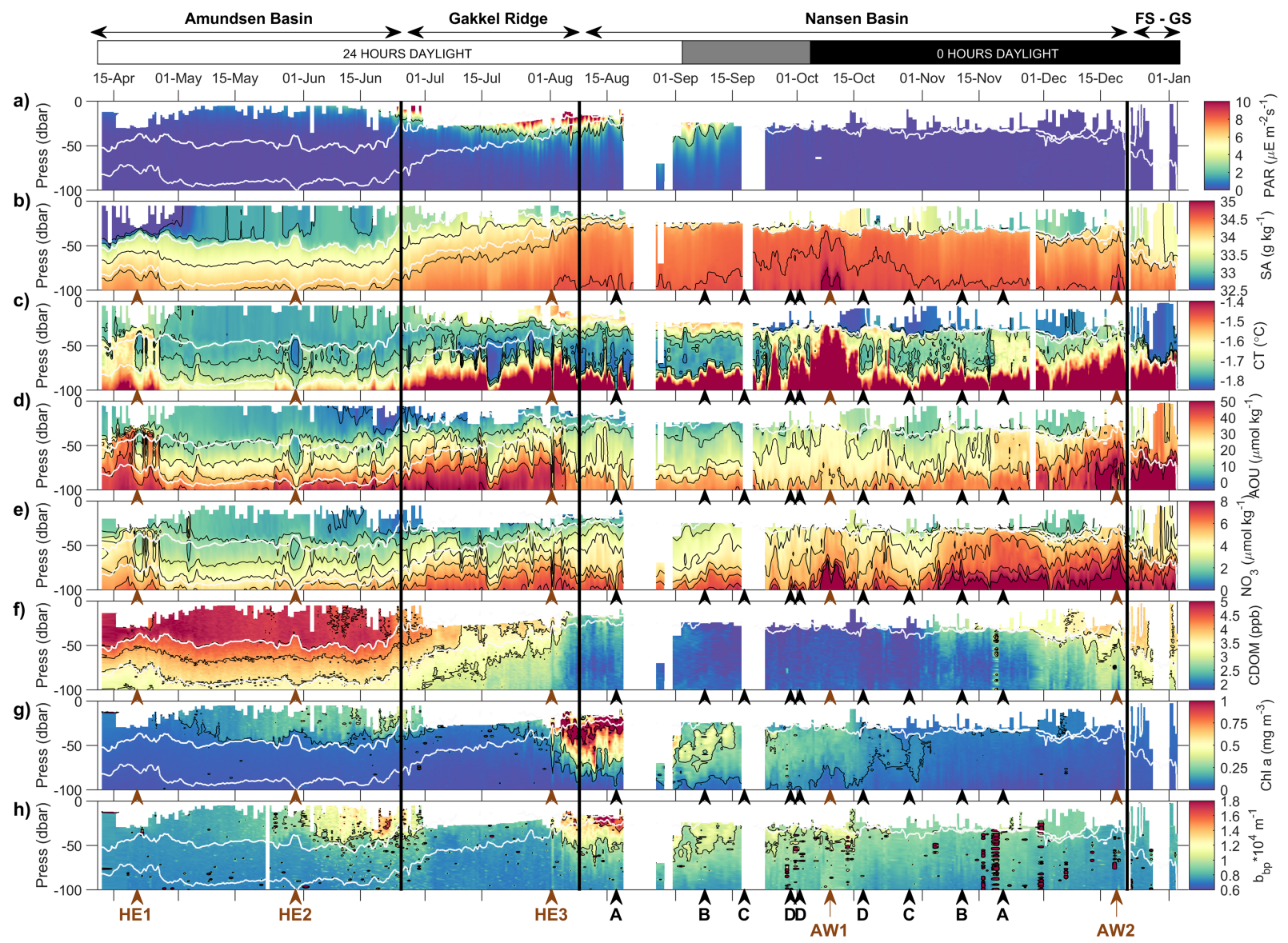

Figure 2. Sections of hydrographic variables along the drift trajectory from 0 to 100 dbar: (a) photosynthetically active radiation (PAR, $\left.\mu \mathrm{E} \mathrm{m}^{-2} \mathrm{~s}^{-1}\right)$, (b) absolute salinity $\left(\mathrm{SA}, \mathrm{g} \mathrm{kg}^{-1}\right)$, (c) conservative temperature (CT, $\left.{ }^{\circ} \mathrm{C}\right)$, (d) apparent oxygen utilization (AOU, $\left.\mu \mathrm{mol} \mathrm{kg}{ }^{-1}\right),(\mathrm{e})$ nitrate $\left(\mathrm{NO}_{3}, \mu \mathrm{mol} \mathrm{kg}{ }^{-1}\right),(\mathrm{f})$ colored dissolved organic matter fluorescence (CDOM, ppb), (g) chlorophyll $a\left(\mathrm{Chl} a, \mathrm{mg} \mathrm{m}^{-3}\right.$ ), and (h) backscatter $\left(\mathrm{b}_{\mathrm{bp}}, \mathrm{m}^{-1}\right)$. $\mathrm{NO}_{3}$, Chl $a, b_{\mathrm{bp}}$, and $\mathrm{CDOM}$ were retrieved from IAOOS 23, while SA, CT, and AOU data were averaged from both profilers' data sets. White lines depict density isolines at 26.7 and $27.3 \mathrm{~kg} \mathrm{~m}^{-3}$; black lines are isolines of respective variables. The limits of the four regions (denoted in magenta on Figures 1a, 1c, and 1d) are marked with vertical black lines; the names of the four regions are written above. The hours of daylight are also shown at the top of the figure. Positions of HE1, HE2, AW1, AW2, and the four crossing points are marked at the bottom.

the maximum depth-integrated Chl $a$ between 5 and $50 \mathrm{~m}$ was $11.0 \mathrm{mg} \mathrm{m}^{-2}$ on $22 \mathrm{June}$-orange profile in Figure 4a). Chl $a$ and backscatter profiles were vertically uniform within the surface layer, suggestive of rapid mixing. Over the period of the bloom, nitrate in the mixed layer was depleted gradually from $\sim 2 \mu \mathrm{mol} \mathrm{kg}{ }^{-1}$ to $<1 \mu \mathrm{mol} \mathrm{kg}{ }^{-1}$ (below the limit of instrument detection), and AOU decreased from 5 to $-4 \mu \mathrm{mol} \mathrm{kg}{ }^{-1}$ (Figures $4 \mathrm{~d}$ and $4 \mathrm{e}$ ). Both Chl $a$ and $b_{\mathrm{bp}}$ in the mixed layer began to decrease at the end of June ( $\sim 30 \%$ declines from 25 to 30 June).

\subsubsection{Summer Bloom in Nansen Basin}

A second more substantial under-ice bloom was encountered in August, as the platforms entered Nansen Basin (Figure 2g, profiles in Figure 5). The environmental conditions during this "summer" bloom were significantly different from those during the spring bloom. The mixed layer became shallower over the Gakkel Ridge due in part to the shoaling of Modified Atlantic Water below (Athanase et al., 2019), which also brought water with greater AOU and nitrate concentrations toward the surface (Figures 2b, 2d, and 2e). Rapid basal ice melt in July and August (Figure 3c) also likely contributed to the formation of a sharp, shallow pycnocline; as ice melt and surface warming continued through autumn, the pycnocline progressively deepened and sharpened. In comparison to Amundsen Basin surface waters, the upper $100 \mathrm{~m}$ in Nansen Basin were depleted in CDOM (1.5-2.5 ppb) and enriched in nitrate (2$7 \mu \mathrm{mol} \mathrm{kg}^{-1}$ ) (Figures 2e-2f). 

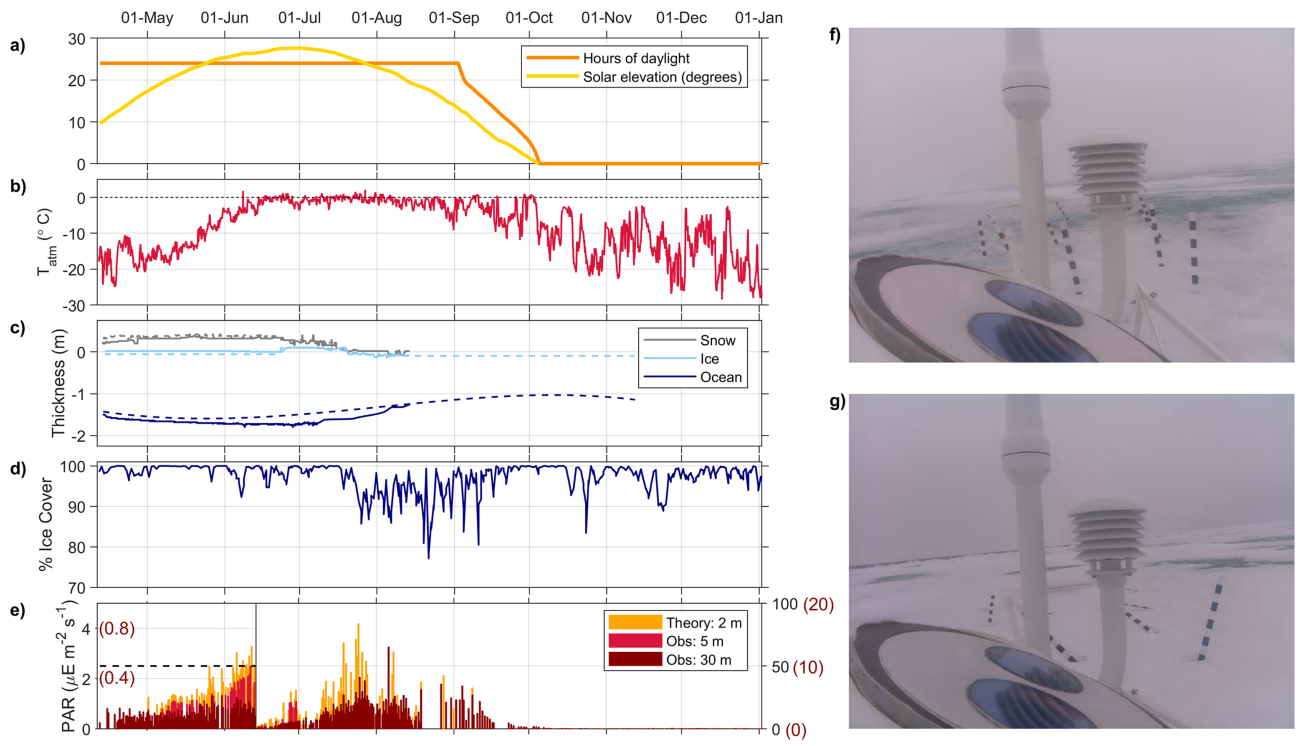

Figure 3. Snow, ice, and light availability. (a) Hours of daylight (orange) and solar elevation (yellow) along the drift calculated with equations (1)-(3). (b) Atmospheric temperature recorded by IAOOS 23. (c) Boundaries of the ice and snow layers, with solid lines representing data from IAOOS 23 and dashed lines data from IAOOS 24. Ice and snow thicknesses were derived from SIMBA data (4 hr sampling interval, $2 \mathrm{~cm}$ vertical resolution) using the method described in Provost et al. (2017). (d) Local \% ice cover calculated from AMSR2 satellite data. Ice concentrations were colocated in space and time with the trajectory of the buoy, and the corresponding pixels were extracted. (e) Estimated under-ice PAR at $2 \mathrm{~m}$ (orange), compared with observations at $5 \mathrm{~m}$ (red) and $30 \mathrm{~m}$ (brown). Note the change in $y$ axis limits on $15 \mathrm{June}$; the $2.5 \mu \mathrm{E} \mathrm{m}^{-2} \mathrm{~s}^{-1}$ threshold for primary production is marked as a dashed black line. Also note the different $y$ axes for $\mathrm{PAR}$ at $30 \mathrm{~m}$ (brown numbers in parentheses and for PAR at 2 and $5 \mathrm{~m}$ (black numbers). PAR at $30 \mathrm{~m}$ goes up to $1 \mu \mathrm{E}$ $\mathrm{m}^{-2} \mathrm{~s}^{-1}$ in the first section and to $20 \mu \mathrm{E} \mathrm{m}^{-2} \mathrm{~s}^{-1}$ in the second, while PAR values at 2 and $5 \mathrm{~m}$ are plotted to up to 5 and $100 \mu \mathrm{E} \mathrm{m}^{-2} \mathrm{~s}^{-1}$. (f) Webcam photo from 20 July, showing the surface covered in blue meltwater. (g) Webcam photo from 5 August, showing isolated melt ponds and an open lead in the background.

Determining precisely when the bloom was encountered is challenging, as data near the surface were limited from July onwards. However, Chl $a$ measurements were relatively low $\left(<0.2 \mathrm{mg} \mathrm{m}^{-3}\right)$ below $30 \mathrm{~m}$ in July and a sudden increase in Chl $a$ was observed on 1 August from 25-60 m (Figure 2, blue profiles in Figure 5(a)). The first profile on 1 August at 6:00 am showed a net subsurface maximum at $25 \mathrm{~m}$ of $0.69 \mathrm{mg} \mathrm{m}^{-3} \mathrm{Chl} a$, and the second profile at 18:00 exhibited two subsurface maxima of 1.73 and $1.82 \mathrm{mg} \mathrm{m}^{-3}$ $\mathrm{Chl} a$ at 18.5 and $25.5 \mathrm{~m}$, respectively (Figure 5(a)).

The bloom intensified and progressively deepened (Figure 2(g)), and a maximum depth-integrated Chl $a$ from 20-100 m of $57 \mathrm{mg} \mathrm{m}^{-2}$ was observed on 12 August. Unlike the Amundsen Basin bloom, this bloom descended beneath the shallow mixed layer, attaining concentrations above the statistical range of dark values as deep as $90 \mathrm{~m}$ (Figure 5a). While little data are available within the surface layer during this period, $\mathrm{Chl} a$ and backscatter profiles show subsurface maxima and consistently lower concentrations at the upper edge of the profiler's measurements (Figure 5a).

The platforms drifted into a slightly different water mass on 13 August, characterized by higher $\mathrm{NO}_{3}$ and AOU above $50 \mathrm{~m}$ (Figures $2 \mathrm{~d}$ and 2e, orange profiles in Figures $5 \mathrm{~d}$ and 5e). The bloom remained closer to the surface in this region, with a well-defined subsurface maximum at around 20-22 m, directly beneath the mixed layer. The greatest $\mathrm{Chl} a$ concentration along the $\operatorname{drift}\left(2.84 \mathrm{mg} \mathrm{m}^{-3}\right.$, orange profile Figure 5a) was measured here.

After the untimely instrument outage from 19 to 26 August, Chl $a$ and backscatter were significantly lower. Continual decreases in $\mathrm{Chl} a$ in the upper $100 \mathrm{~m}$ were observed through fall. During the remainder of the drift in Nansen Basin, near-surface Chl $a$ concentrations were low but nonnegligible $\left(0.08 \pm 0.01 \mathrm{mg} \mathrm{m}^{-3}\right.$ from 20-50 m). Chl $a$ profiles exhibited a subsurface maximum at the base of the mixed layer through late November. December profiles resembled those taken in springtime, with vertically homogeneous Chl $a$ in the surface mixed layer. 

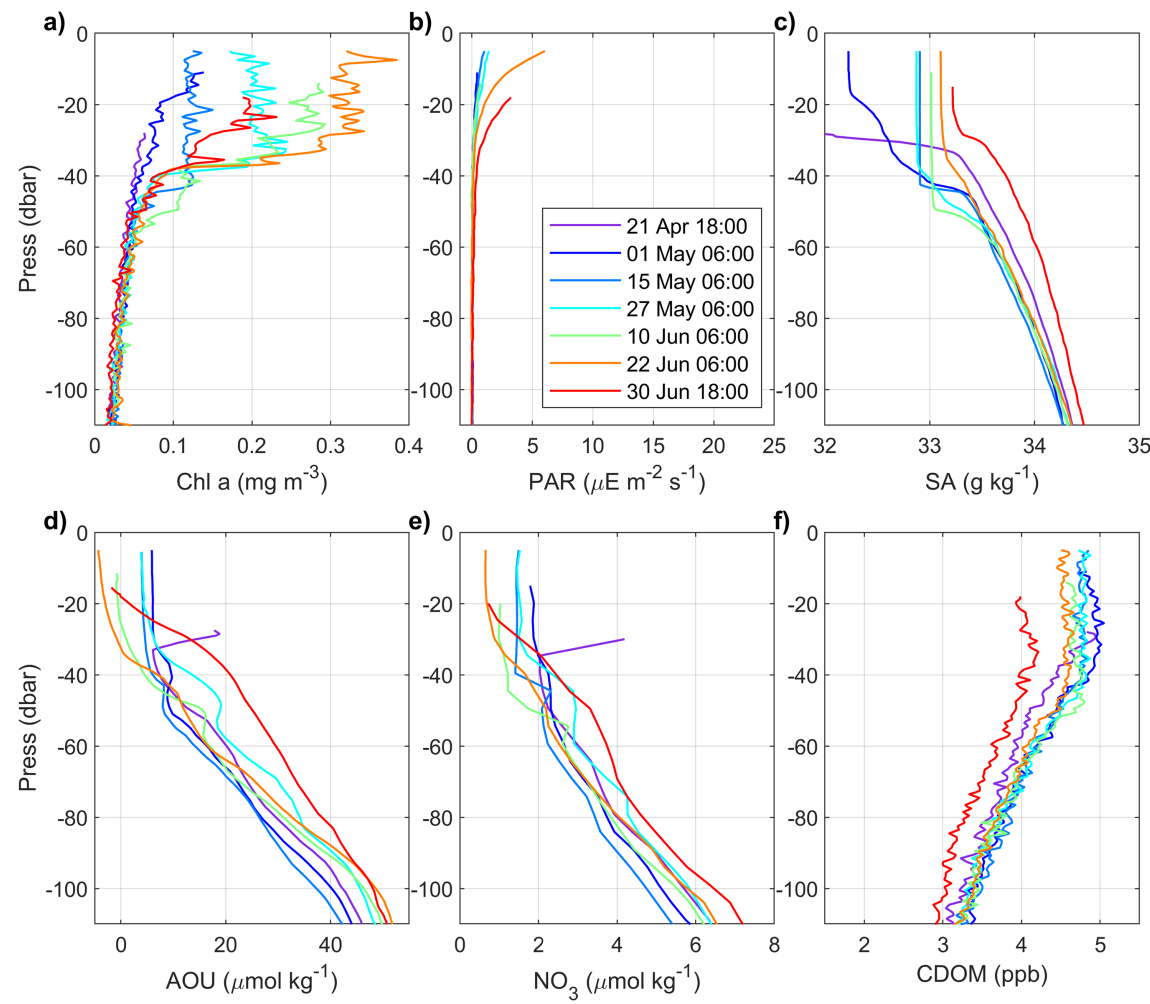

Figure 4. Selected profiles of (a) $\mathrm{Chl} a$, (b) PAR, (c) $\mathrm{SA}$, (d) $\mathrm{AOU}$, (e) $\mathrm{NO}_{3}$, and (f) $\mathrm{CDOM}$ during the spring bloom. The 21 April profile (purple) is during the HE1 encounter, the 27 May profile is during the HE2 encounter, and the 10 June profile occurs during the second crossing of HE2.

\section{Discussion}

\subsection{Limitations}

Before addressing the findings from this data set, a few key limitations must be acknowledged. First, as no observations were made to be able to directly calibrate the measurements, there is a degree of uncertainty in the absolute values for biogeochemical observations. However, the minimal long-term measurement drift, proximity of $\mathrm{Chl} a$ and PAR values at depth to the zero dark value, and comparisons with previous Arctic $\mathrm{NO}_{3}$ measurements (Athanase et al., 2019) all provide substantial validation of the IAOOS data set.

Another source of uncertainty arises from the consideration that quantities such as the backscatter signal and CDOM fluorescence are produced by many processes and compounds, which are difficult to distinguish between. For example, backscatter could in theory be caused by any particulate matter (organic or inorganic), but it is assumed here to be firmly linked to the presence of biological organisms in the water column. This is a reasonable assumption considering the strong correlations found between Chl $a$ and $b_{\mathrm{bp}}$ and the remoteness of the sampling region from sources of inorganic matter such as coastal sediments. However, inorganic sources of the $b_{\mathrm{bp}}$ signal could affect results, particularly calculations of the optical community index.

Finally, the platforms' non-Lagrangian trajectories pose challenges for teasing apart confounding seasonal and spatial influences on biogeochemistry. It cannot be determined definitively whether Chl $a$ concentrations in Nansen Basin are typically larger than those in Amundsen Basin, or whether observed differences are solely due to the seasonality of the sampling. The lack of near-surface measurements also precludes calculations and comparisons of total depth-integrated chlorophyll $a$ and net community production. Given that under-ice blooms often start just beneath the ice and then extend to the subsurface layer, it may be that significant vertical and temporal extents of the blooms were not recorded by the profiler. 

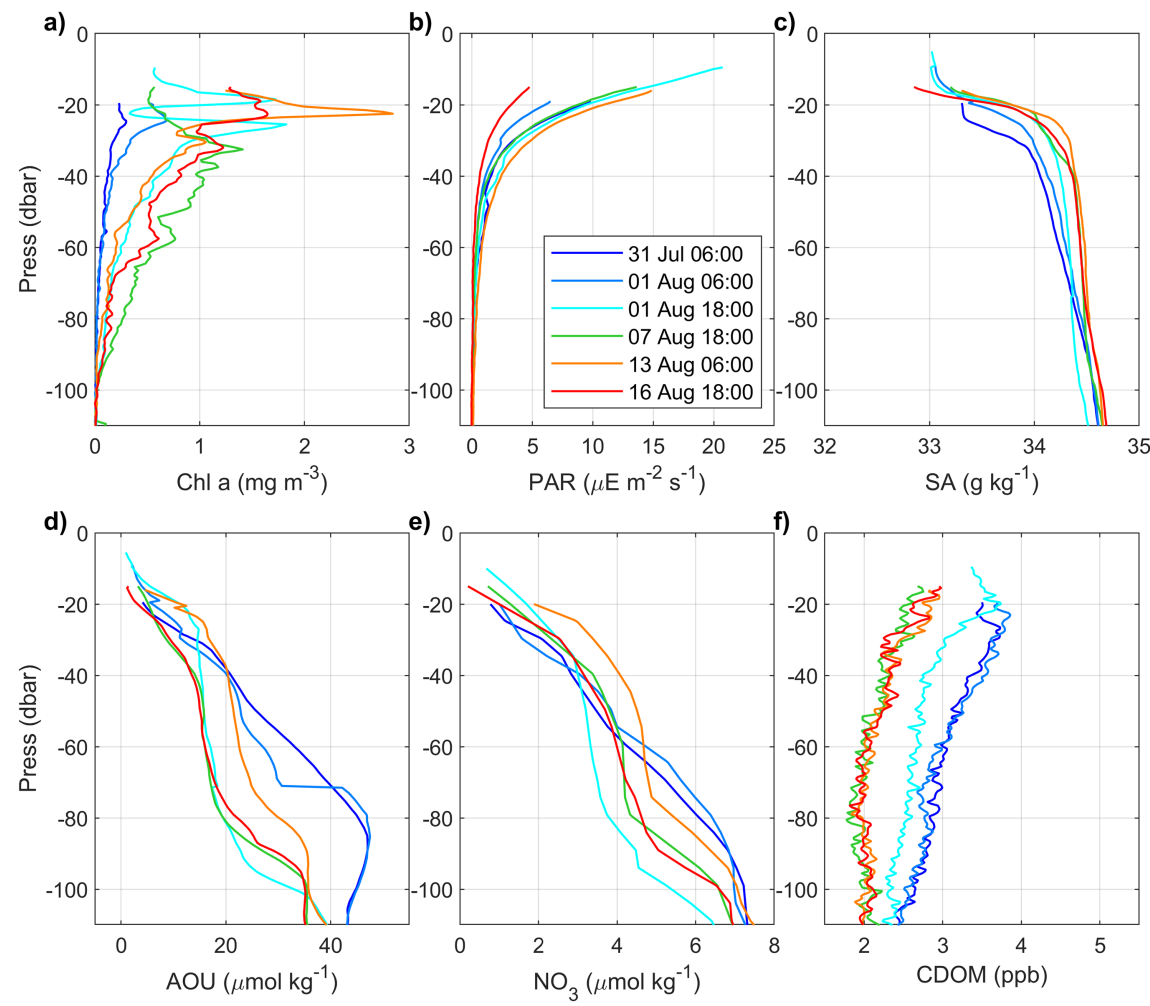

Figure 5. Selected profiles of (a) Chl $a$, (b) PAR, (c) $\mathrm{SA}$, (d) AOU, (e) $\mathrm{NO}_{3}$, and (f) CDOM during the summer bloom. The 1 August profile at 18:00 is the potential encounter with a third halocline eddy (HE3). Green and red profiles are at nearly the same geographical position (7 and 16 August, respectively).

\subsection{Insights on Community Composition of Under-Ice Blooms}

\subsubsection{OCI: Chl $a / b_{\mathrm{bp}}$}

While Chl $a$ concentrations were much larger in the summer bloom than the spring bloom, $b_{\mathrm{bp}}$ was the same order for both (Figure 6a). Ninety-five percent of data points in May, June, and July had OCIs below $0.25 \times 10^{4} \mathrm{mg} \mathrm{m}^{-2}$, with an average OCI of $0.14 \times 10^{4} \mathrm{mg} \mathrm{m}^{-2}$ (Figure $6 \mathrm{~b}$ ). The highest OCIs during this period were found directly beneath the surface, and the probability of higher OCIs progressively decreased with depth (Figure 6c). In August, the average OCI was almost 4 times greater $\left(0.54 \times 10^{4} \mathrm{mg} \mathrm{m}^{-2}\right)$ and there was a larger variety in the individual ratios (STD of $0.26 \times 10^{4}$ ) (Figure $6 \mathrm{~b}$ ). The probability of high OCI values in August was greatest between 20 and $50 \mathrm{~m}$; from $10-20 \mathrm{~m}$ and below $50 \mathrm{~m}$ there was a greater diversity of OCI ratios (Figure 6c). The average OCI declined as $\mathrm{Chl} a$ concentrations began to decrease in September, and the range of OCIs in October largely resembled those in May and June. However, unlike in the springtime, the greatest OCIs remained beneath $40 \mathrm{~m}$ in September and October. In November and December, all OCI values were below $0.15 \times 10^{4} \mathrm{mg} \mathrm{m}^{-2}$.

It is expected that populations of small phytoplankton exhibit smaller OCIs, while phytoplankton of larger class sizes exhibit greater ones (Cetinić et al., 2015). In particular, Cetinić et al. (2015) observed a strong correlation between the $\mathrm{OCI}$ and the fraction of planktonic carbon due to diatoms. Following these findings, the differences between the two blooms' OCIs suggest that the spring bloom was composed primarily of small phytoplankton, while the summer bloom initially had a greater number of large phytoplankton and a more diverse population overall. As light levels declined in autumn and the summer bloom faded, there were progressively fewer large phytoplankton and smaller organisms regained dominance. Previous taxonomic analyses of under-ice blooms support these inferences. There is increasing evidence that communities of small flagellates, some of which may be mixotrophic (organisms with the ability to derive energy from both autotrophy and heterotrophy), are dominant under Arctic ice throughout most of the year (Lovejoy, 2014; Olli et al., 2007). Results from Olli et al. (2007), Gosselin et al. (1997), and Booth and Horner (1997) concur 

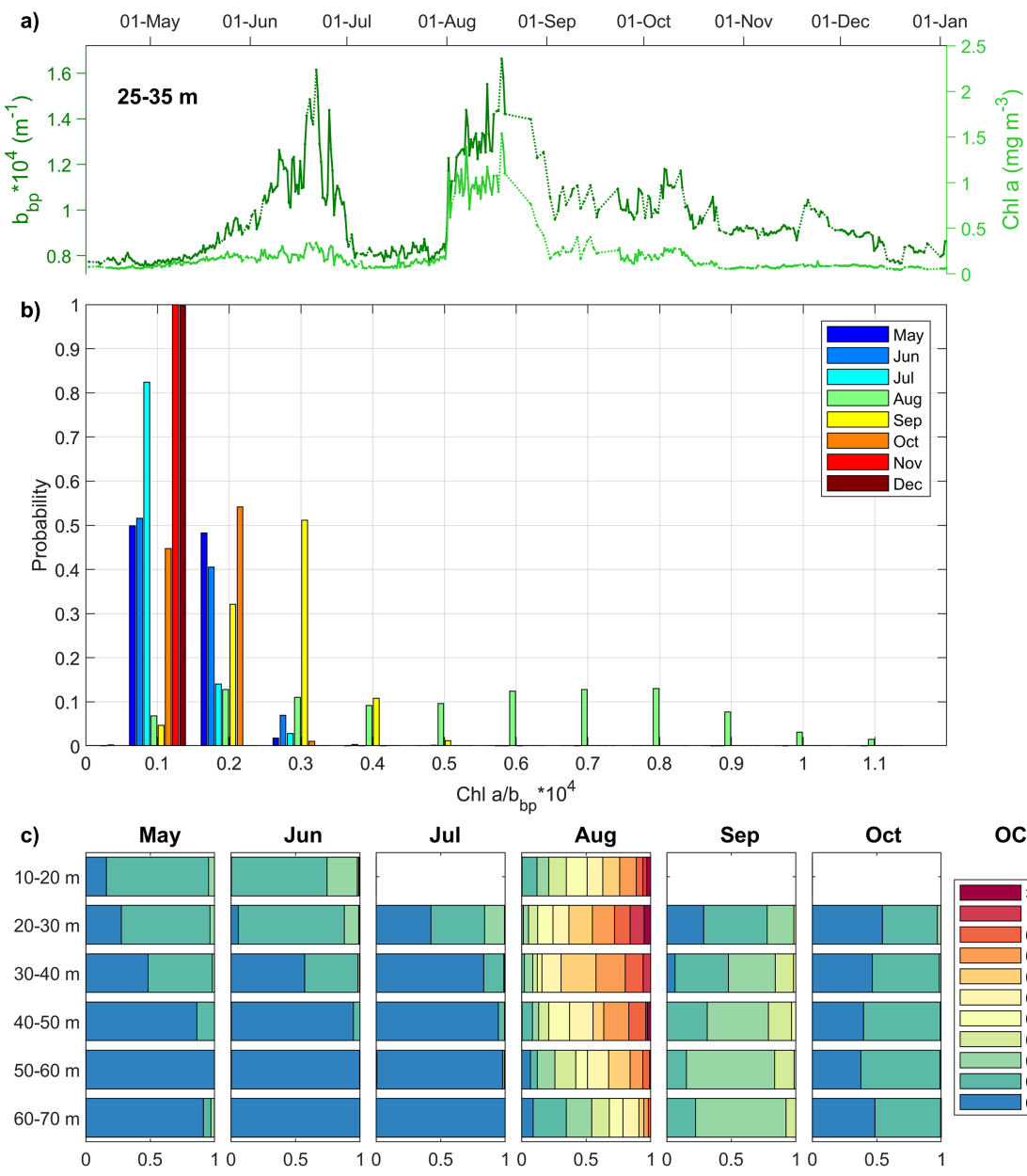

OCI

Figure 6. (a) Vertical averages from 25-35 $\mathrm{m}$ of $b_{\mathrm{bp}}$ and Chl $a$ along the drift. (b) Histogram of $\mathrm{Chl} a / b_{\mathrm{bp}}$ ratios calculated for each data point between 30 and $50 \mathrm{~m}$, separated by month. Bin counts were divided by the total number of data points each month to calculate the probability of each ratio range's occurrence. (c) OCI probabilities in 10-m depth increments, separated by months from May through October. Insufficient data were available in the upper 10-20 m for July, September, and October.

that small flagellates, dinoflagellates, and to a lesser extent diatoms, dominate the central Arctic Ocean in summertime. Additionally, Gosselin et al. (1997) observed in August that a greater fraction of phytoplankton were of a larger class size $(>5 \mu \mathrm{m})$ in Nansen Basin than in Amundsen Basin. Both spatial and seasonal factors must therefore be considered when interpreting the IAOOS data set. The smaller class sizes in Amundsen Basin are likely a result of reduced nutrient availability, as smaller phytoplankton gain dominance in oligotrophic environments ( $\mathrm{Li}$ et al., 2009). Amundsen Basin may contain a greater proportion of small phytoplankton than Nansen Basin year-round, but lower light in springtime is also expected to have favored small phytoplankton at the beginning of the drift.

In addition to community composition, species-specific physiological variability and the presence of heterotrophic organisms may also alter the optical community index. Chl a production by phytoplankton can be reduced by solar quenching (Brunet et al., 2011; Cetinić et al., 2015), but this is unlikely to be significant at the low PAR levels during the spring bloom or at the depths sampled during the summer bloom (below $10 \mathrm{~m}$ ). Conversely, photoacclimation to low light levels during the spring bloom would result in higher Chl $a$ to carbon ratios than in the summer bloom, but the opposite is true here. Nutrient stress can also reduce Chl $a$ production (Brunet et al., 2011; Cetinić et al., 2015); considering the low nitrate concentrations in Amundsen Basin compared to Nansen Basin, this may contribute to the difference in OCIs between the two blooms. Additionally, $b_{\mathrm{bp}}$ is a function of both autotrophic and heterotrophic carbon, and a larger 

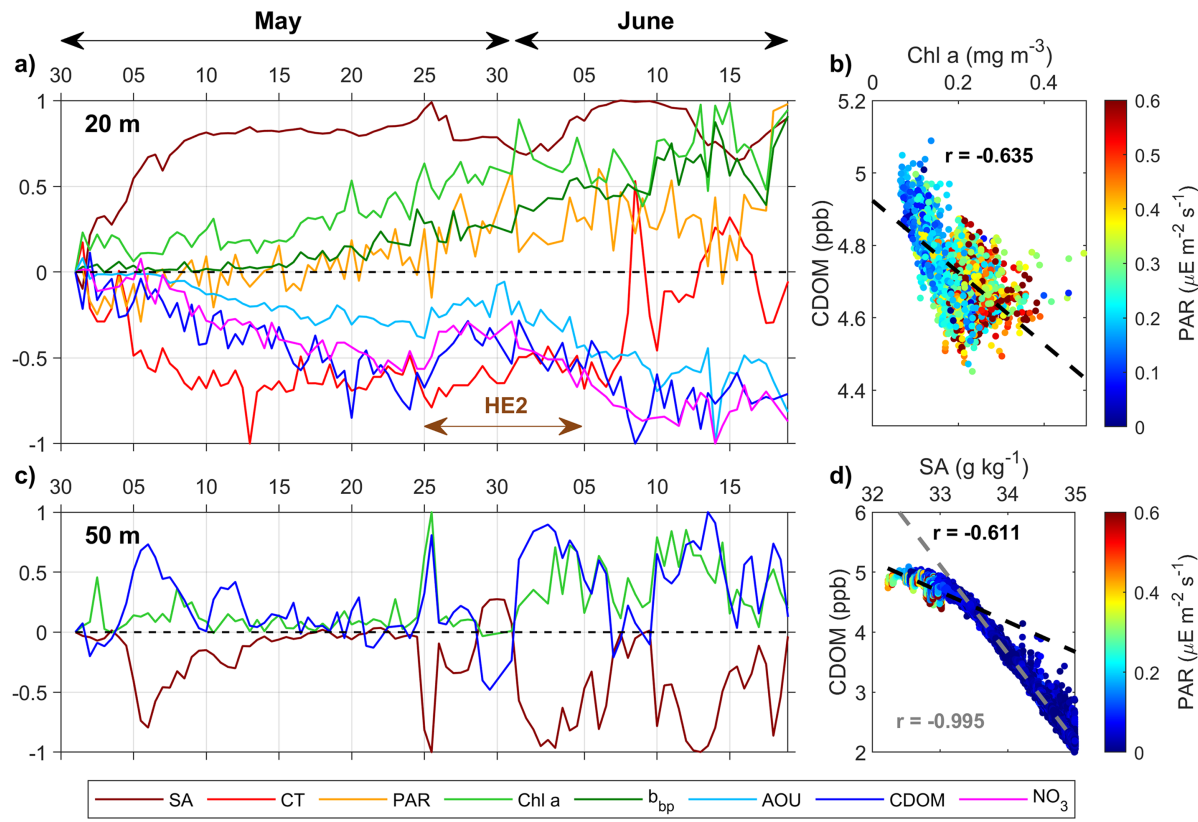

Figure 7. (a) Normalized differences in measured variables at 20-m depth between values on 1 May and subsequent profiles during the spring bloom $\left(\chi(t)-\chi_{\text {initial }}\right.$. (b) Scatter plot of CDOM versus Chl $a$ from 15-30 m, with PAR in color. The linear regression is superimposed as a dashed black line, with its correlation coefficient (r) displayed above. (c) Same as (a) except at $50 \mathrm{~m}$, showing only SA, Chl $a$, and CDOM. (d) Scatter plot of CDOM versus SA for the full $250 \mathrm{~m}$, with PAR in color. The dashed gray line is the linear regression for data points below $60 \mathrm{~m}$, while the dashed black line is the linear regression for data points above $30 \mathrm{~m}$.

fraction of carbon from heterotrophs would also cause the OCI to decrease (Cetinić et al., 2015). Without shipboard measurements to confirm nutrient stress or heterotrophic carbon concentrations, it is difficult to ascertain how these factors contribute to the observed OCIs. Surface CDOM measurements can however provide additional insights.

\subsubsection{Biologically Mediated Removal of CDOM}

Large-scale trends in the IAOOS CDOM measurements, outlined in section 3.2, reflect changes in hydrography along the platform drift. Near-surface CDOM concentrations are low in Nansen Basin and high in the central Arctic transpolar drift, a signal previously linked to terrestrial input of DOM-enriched waters on the Siberian shelves, advected across the Arctic in the Transpolar Drift (Gonçalves-Araujo et al., 2018; Lund-Hansen et al., 2015; Stedmon et al., 2011). High CDOM in the surface ocean at the end of the drift (Figure 2f) has been associated with the same terrestrial DOM input observed in Amundsen Basin, here observed in polar surface waters exiting the Arctic within the East Greenland Current (Granskog et al., 2012; Pavlov et al., 2015).

A subtler evolution in CDOM is observed in the mixed layer in Amundsen Basin. Continuous decreases in CDOM (-9.4\% averaged over the upper $40 \mathrm{~m}$ from 1 May through mid-June) suggest influences other than basin-wide hydrography. The normalized differences between values on 1 May and subsequent measurements in the mixed layer during the spring bloom reveal that the decline in CDOM largely mirrors increases in PAR, Chl $a$, and $\mathrm{b}_{\mathrm{bp}}$ and resembles decreases in $\mathrm{AOU}$ and $\mathrm{NO}_{3}$ (Figures $7 \mathrm{a}$ and $7 \mathrm{~b}$ ). While CDOM is closely coupled with salinity below the mixed layer $(r=-0.995)$, the relationship in the surface layer is weaker $(r=-0.611$ ) (Figures 7c and 7d). No significant change was observed in CDOM in the surface layer in Nansen Basin (Figure S3).

Granskog et al. (2012) determined that 49-59\% of CDOM absorption between 250 and $600 \mathrm{~nm}$ is lost between Arctic river discharge and Arctic outflow through Fram Strait, and several other studies have documented the lability of dissolved organic matter or carbon in the Arctic (e.g., Alling et al., 2010; Letscher et al., 2011). Removal of CDOM from the surface ocean can occur as a result of photochemistry, ice processes, and biological activity. Photobleaching or photomineralization may have played a role in the decline of CDOM in 
Table 2

Summary of Biogeochemical Characteristics During the Spring Bloom and Summer Bloom

\begin{tabular}{|c|c|c|}
\hline & Spring bloom & Summer bloom \\
\hline Dates observed & May-June & August-October \\
\hline Region & Amundsen Basin & Nansen Basin \\
\hline $\begin{array}{l}\text { Chl } a \text { at profile } \\
\text { maximum }\left(\mathrm{mg} \mathrm{m}^{-3}\right)\end{array}$ & $0.27 \pm 0.16^{\mathrm{a}}(0.11-2.11)^{\mathrm{a}}$ & $\begin{array}{c}\text { (Aug) } 1.48 \pm 0.57^{b} \\
\left(\text { Sep-Oct) } 0.28 \pm 0.13^{c}\right. \\
(0.25-2.84)^{b}\end{array}$ \\
\hline PAR at $30 \mathrm{~m}\left(\mu \mathrm{E} \mathrm{m}^{-2} \mathrm{~s}^{-1}\right)$ & $0.25 \pm 0.27(0-1.17)$ & $\begin{array}{c}\text { (Aug) } 3.47 \pm 2.24 \\
(\text { Sep-Oct) } 0.75 \pm 1.49(0-13.03)\end{array}$ \\
\hline OCI & $1500 \pm 700$ & $\begin{array}{c}\text { (Aug) } 4,800 \pm 2,800 \\
\text { (Sep-Oct) } 1,700 \pm 800\end{array}$ \\
\hline $\mathrm{AOU} / \mathrm{NO}_{3}$ & $\sim 9.1$ & $\sim 5.9$ \\
\hline $\begin{array}{l}\text { Suspected planktonic } \\
\text { function/size type }\end{array}$ & $\begin{array}{l}\text { Small organisms } \\
\text { (e.g. flagellates, dinoflagellates), } \\
\text { potentially mixotrophic }\end{array}$ & $\begin{array}{l}\text { Codominance of large } \\
\text { (e.g. diatoms) and } \\
\text { small organisms }\end{array}$ \\
\hline
\end{tabular}

Note. For Chl $a$, PAR and OCIs, the mean and standard deviation are presented, with the range in parentheses. Upper bounds on $\mathrm{Chl} a$ vary due to the fact that the shallowest depth reached by the profiler changed along the drift.

${ }^{\mathrm{a}}$ From $5 \mathrm{~m}$. ${ }^{\mathrm{b}}$ From $20 \mathrm{~m}$. ${ }^{\mathrm{c}}$ From $30 \mathrm{~m}$.

Amundsen Basin (Para et al., 2013), especially as PAR increases linearly over the period that CDOM decreases. Considering the thick ice cover and extremely minimal under-ice light during the springtime drift, however, it is unlikely that photochemistry contributed significantly to the observed CDOM decrease. There remains much uncertainty as to how ice processes affect CDOM concentrations, but field studies have found that sea ice formation increases surface CDOM (Para et al., 2013), while sea ice melt dilutes under-ice water and decreases CDOM concentrations (Granskog et al., 2015). The sea ice at IAOOS 23 thickens continuously until July (Figure 3b), so this should contribute to an overall increase in CDOM rather than the decrease observed.

It is therefore likely that the decrease is linked to biological activity. Bacterial production may be particularly high in this region due to the enriched CDOM in the mixed layer, producing an imbalance between heterotrophic and autotrophic organisms as suggested by Rich et al. (1997). Another possibility is that organisms found in this region are mixotrophic. Optical IAOOS measurements alone cannot expose the nutrition strategies of individual organisms encountered and definitively identify mixotrophic, autotrophic, or heterotrophic protists and bacteria. However, previous studies have found that planktonic bacterivory is common in oligotrophic regimes as it can help relieve nutrient limitation (Sanders \& Gast, 2012; Stoecker et al., 2017) and a phylogenetic diversity of potentially mixotrophic species have been identified in the Arctic Ocean, including flagellates (e.g., chrysophytes), dinoflagellates, and certain ciliates (Lovejoy, 2014; Stoecker et al., 2017). Considering the high CDOM concentrations and relatively low light and nutrient levels during the drift in Amundsen Basin, osmotrophy and bactivory would be viable alternatives to phototrophic nutrition. A higher concentration of heterotrophic or mixotrophic organisms in Amundsen Basin could also help explain the lower OCIs in this region.

\subsection{Factors Governing Under-Ice Blooms}

The characteristics of the two blooms and their distinct environmental conditions are summarized in Table 2 . The differences between the blooms reflect the spatial inhomogeneity of under-ice primary production as well as variations across seasons.

\subsubsection{Light Limitation}

Several previous Arctic field studies documented under-ice blooms that were initiated by the onset of ice melt, which increases light transmittance through the ice and induces a shoaling of the mixed layer (e.g. Laney et al., 2014; Mundy et al., 2014). The Nansen Basin summer bloom was likely controlled by the same factors, as it aligned with a warming and freshening of the surface layer and a rapid thinning of the above ice (Figures 2b, 2c, and 3). Strong light transmittance and a deep euphotic zone allowed the bloom to expand far beneath the mixed layer. Although data in the upper $20 \mathrm{~m}$ are missing, what can be observed of the bloom's vertical structure resembles observations by Assmy et al. (2017) and Mundy et al. (2009), which 
both showed a subsurface maximum that descended progressively as nutrients were utilized in the surface layer. The end of the summer bloom aligned with the transition into polar night, and while some Chl $a$ remained in the surface layer after August, the decrease in Chl $a$ suggests that losses from grazing or sinking outweighed additional primary production.

In contrast, the spring bloom developed before any significant melting occurred, when light levels were very low. In fact, the commonly used threshold PAR value required for photosynthesis by under-ice phytoplankton, $2.5 \mu \mathrm{E} \mathrm{m}^{-2} \mathrm{~s}^{-1}$ (e.g., Palmer et al., 2011), was only reached at the beginning of June, almost a month after Chl $a$ began increasing in the mixed layer. Chl $a$ concentrations increased simultaneously to light transmittance, suggesting that light was a key factor in the development of the spring bloom. While snow and ice cover were thick during this time period, nearby leads could have provided enough light to initiate the bloom, as observed by Assmy et al. (2017). However, if mixotrophy was indeed significant during springtime, this could also have allowed the bloom to develop with very limited light. Blooms documented previously in the Eurasian central Arctic in July through September exhibited Chl $a$ concentrations of the same order of magnitude (Gosselin et al., 1997; Laney et al., 2014; Lund-Hansen et al., 2015; Olli et al., 2007), and similar vertical structures showing Chl $a$ confined to the mixed layer (Laney et al., 2014). As far could be found from literature review, the spring bloom observed by IAOOS 23 is the first record of under-ice primary production this early in the year in Amundsen Basin. Neither ITP48 (2011-2012) nor ITP93 (2015-2016), which both returned more than a year of data in the central Arctic, observed blooms during May and June (despite similar PAR values to IAOOS 23 for ITP93) (Laney et al., 2014, http://www.whoi.edu/itp). Although the spring bloom was small in magnitude, IAOOS observations suggest that phytoplankton growth can occur in environments with much less light than previously thought necessary and that growth seasons and spatial boundaries of under-ice production may already be expanding in a warming Arctic.

\subsubsection{Nutrient Limitation, Stratification, and the Potential Role of Eddies}

The availability of nitrate for primary production varied significantly along the platforms' drift. In Amundsen Basin, the average AOU: $\mathrm{NO}_{3}$ molar ratio in the near-surface productive layer was $~ 9.1$ $(r=0.90)$, close to the expected Redfield ratio of $\sim 8.65$. However, in Nansen Basin the ratio was $\sim 5.9$ $(r=0.89)$, significantly lower than Redfield. The lower ratio is likely a result of upwelling Atlantic Water that brings water enriched in nitrate toward surface (Codispoti et al., 2013). While Codispoti et al. (2013) infer that elevated nitrate concentrations near the surface in the Eurasian Basin in summertime suggest that light or grazing are limiting, Randelhoff and Guthrie (2016) argue that production in Amundsen Basin and much of Nansen Basin are nutrient limited (excluding the region near the Yermak Plateau). Events of seasonal surface oligotrophy, coupled with a deep photic zone, have previously been observed in the region (Strass \& Nöthig, 1996). IAOOS 23 measurements suggest significant nitrate utilization and potential limitation during both blooms. In springtime concentrations were no higher than $2 \mu \mathrm{mol} \mathrm{kg}{ }^{-1}$ and were reduced to less than $1 \mu \mathrm{mol} \mathrm{kg} \mathrm{k}^{-1}$ by the end of June. It may be that the demise of the spring bloom was a result of this reduction in nitrate. In summertime $\mathrm{NO}_{3}$ values were also less than $1 \mu \mathrm{mol} \mathrm{kg} \mathrm{k}^{-1}$ at the upper boundary of measurements from 5 to 12 August, suggesting at least a short period of surface oligotrophy. The lack of surface nutrients, coupled with a well-lit environment, would explain the summer bloom's descent into relatively nitrate-enriched water below the mixed layer.

Considering a potentially increasing importance of nutrient limitation of Eurasian Basin phytoplankton growth as light limitation is reduced, it is worth examining additional sources of nutrients in the Central Arctic. Eddies are known to transport Arctic shelf-origin waters offshore (Bluhm et al., 2015), and could provide an effective mechanism for lateral advection of not only salt and heat but also nutrients from the shelves to the basin interior. In particular, offshoots and eddies formed from the Atlantic Water Boundary Current are expected to be quite common (Våge et al., 2016). Halocline eddies in the central Arctic are less studied but still well documented (Zhao et al., 2014).

Halocline eddies (HE1 and HE2, Figure 2) and Atlantic Water mesoscale structures (AW1 and AW2, Figure 2) encountered during the IAOOS drift are documented in Athanase et al. (2019). During encounters with halocline eddies and Atlantic Water mesoscale structures, the pycnocline shoaled (Figures 2 and 4c). In theory, the thinner mixed layer above the eddies should confine phytoplankton to shallower depths, keeping them well supplied with light and supporting the development of a bloom. Above HE2, AW1, and AW2 (measurements are lacking above HE1), the strength of the pycnocline's stratification decreased 


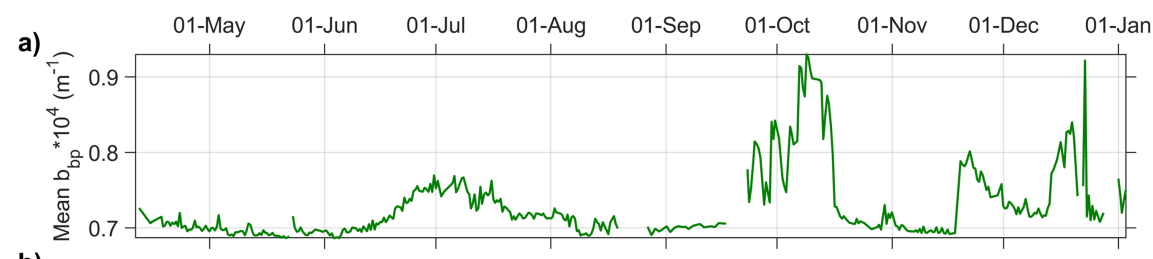

b)

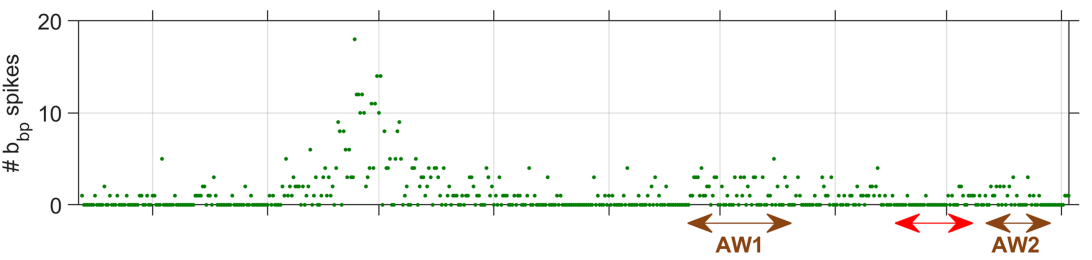

Figure 8. (a) Depth-averaged $b_{\mathrm{bp}}$ from 150 to $250 \mathrm{~m}$, with all values greater than $10^{-4} \mathrm{~m}^{-1}$ removed. (b) Total spike count for each profile from 150-250 m, calculated as a positive deviation of greater than $3 \%$ from the average of the two measurements directly above and two below. Positions of AW1 and AW2 are marked with brown arrows at the bottom of the figure, and the red arrow indicates the period where $b_{\mathrm{bp}}$ measurements should be treated with caution.

(maximum value of Brunt-Väisälä frequency reduced as much as $70 \%$ ). AOU and $\mathrm{NO}_{3}$ were somewhat greater in the mixed layer directly above $\mathrm{HE} 2\left(\Delta \mathrm{NO}_{3} \sim+1 \mu \mathrm{mol} \mathrm{kg}{ }^{-1}, \Delta \mathrm{AOU} \sim+2.5 \mu \mathrm{mol} \mathrm{kg}^{-1}\right.$, Figures 2, 4d, 4e, and 7a), despite overall decreases in nitrate and AOU during the spring bloom; these increases suggest that HE2's anticyclonic rotation (Athanase et al., 2019) may have sustained upwelling of deeper, nutrient-enriched water that supported phytoplankton growth.

The rapid increase in Chl $a$ on 1 August may have also been caused by a passing eddy (Figures $2 \mathrm{~g}$ and 5a). The increase coincided with unusual profiles in all other oceanographic variables, which largely resembled those found in HE1 and HE2. Specifically, the pycnocline shoaled directly above a minimum in temperature, nitrate, AOU and CDOM (Figures 2 and 5). Rigorous classification as a halocline eddy is not possible as the buoy only captured two anomalous profiles, but the fact that these changes were observed in all variables suggests that the platform may have clipped the side of an additional eddy (marked as HE3 in Figure 2). The rapid increase in Chl $a$ supports the hypothesis that eddy-induced upwelling or horizontal transport could help sustain Arctic phytoplankton blooms.

Weakened stratification and enhanced vertical mixing have also been correlated with the atlantification of the Eurasian Basin (Lind et al., 2018; Polyakov et al., 2017; Randelhoff et al., 2018). There may be a more important biophysical role for Atlantic Water intrusions in the future if increased ice melt leads to less light limitation, stronger stratification, and more pronounced nutrient depletion in the surface layer.

\subsection{Organic Particle Export}

Organic particle export from the surface layer to depth may also be associated with changes in stratification. As ice began to melt in the region of the Gakkel Ridge, the mixed layer shoaled and the density gradient at the base of the mixed layer weakened (Figure 2). In June and July, coincident with the period of mixed layer shoaling, depth-integrated $b_{\mathrm{bp}}$ between 150 and $250 \mathrm{~m}$ increased by $10 \%$ from baseline values (Figure 8a). An increase in backscatter spikes (empirically determined as data points over 3\% higher than the average of the two measurements directly above and two below) is concurrently observed (Figure 8b). Both increases in total backscatter and in spikes are not uniform over the $250 \mathrm{~m}$ profiles, suggesting that these changes are not a result of instrumental drift. Laney et al. (2017) document a similar increase in Chl $a$ spikes below the euphotic zone beginning mid-July in the central Arctic, coinciding with the shoaling of the mixed layer, and suggest that these may be caused by large aggregates of sinking algal matter. While no significant corresponding signal of Chl a spikes was observed by IAOOS 23, the backscatter increase supports the assumption of particle export during mixed layer shoaling. Another potential source of backscatter is sea ice algae and organic matter released into the water column during basal ice melt (Boetius et al., 2013). 

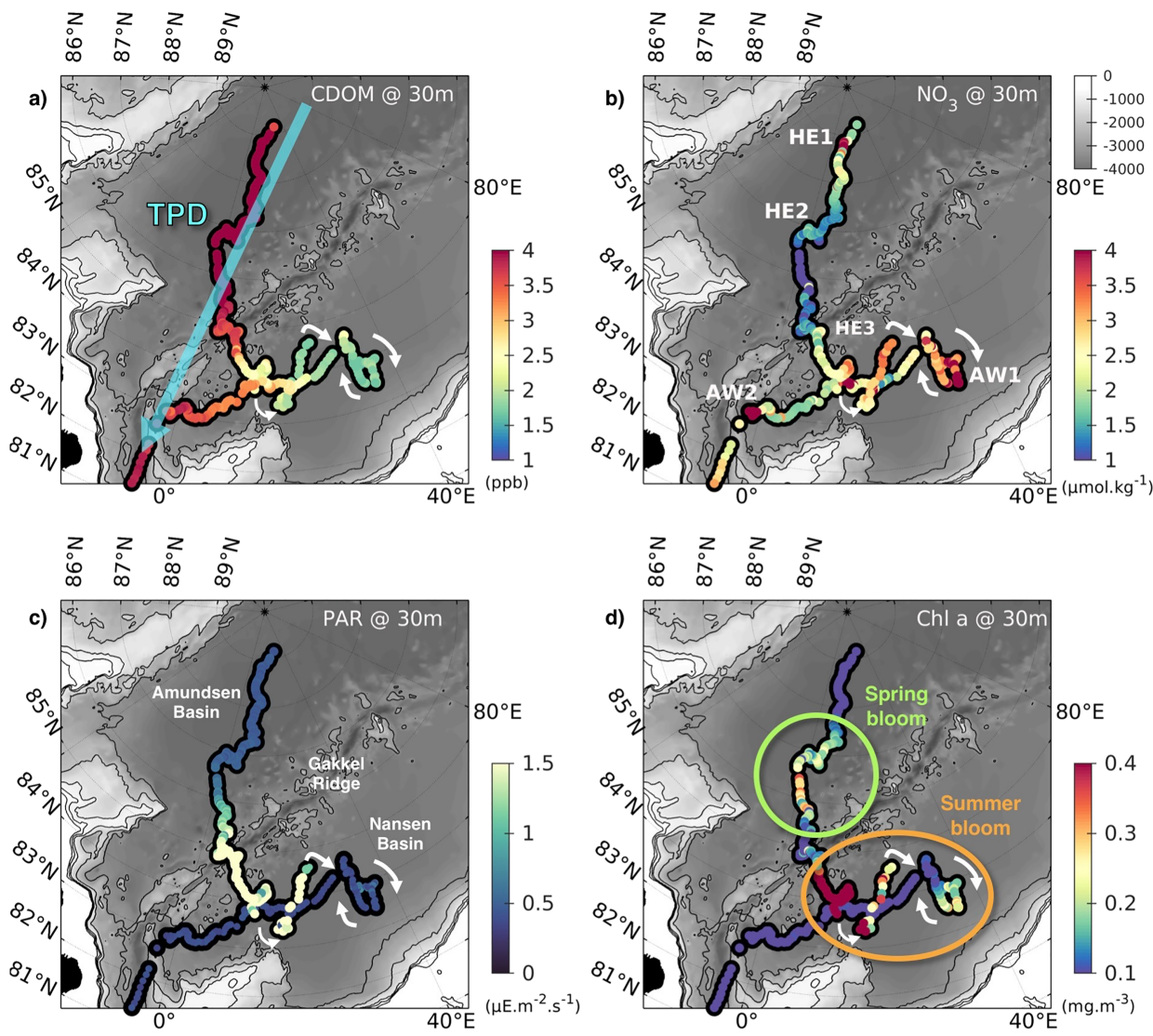

Figure 9. Maps of select variables along the drift at $30 \mathrm{~m}$ : (a) CDOM, with the blue arrow overlay representing the transpolar drift, (b) $\mathrm{NO}_{3}$, (c) PAR, and (d) Chl $a$. White arrows mark the direction of the platforms' drift.

\section{Conclusion}

The unique IAOOS time series document 8 months of hydrography and biogeochemistry in the remote Eurasian Arctic, a region that has historically been sparsely sampled. The data reveal high CDOM concentrations in the transpolar drift which may provide sustenance for under-ice biological communities, possible instances of mesoscale-driven nitrate upwelling, nitrate limitation over the Gakkel Ridge, and the presence of phytoplankton blooms despite minimal light for most of the drift (Figure 9). Two distinct under-ice blooms were observed along the drift, including a small bloom in late spring that may be the first record of under-ice primary production this early in the year in Amundsen Basin. The data set demonstrates the heterogeneity in Arctic under-ice biology both spatially and seasonally and attests to the need for increased measurements in this rapidly changing region of the Arctic.

Additional instruments on future ice-tethered platforms could help disentangle the many biological, chemical, and dynamical processes occurring under Arctic sea ice. For example, hyperspectral radiometry or variable fluorescence instruments could provide information about community composition and photosynthetic states (Laney et al., 2014). Additionally, measuring the spectrum of CDOM absorbance would help distinguish between sources and sinks of dissolved organic matter and carbon and perhaps provide clues as to the importance of mixotrophy in the central Arctic. Other instruments that measure vertical mixing or zooplankton biomass would also enhance our understanding of under-ice processes and the limiting factors governing primary production.

Despite certain limitations, the IAOOS platform's high-resolution, long-term biogeochemical data set is an invaluable addition to the current archive of Arctic observations. As Arctic ice cover, stratification and nutrient supply evolve, there remains much uncertainty about how Arctic ecosystems will respond. Advancing understanding of the baseline state of Arctic ecosystems and our ability to document subsequent changes, 
Acknowledgments

We are deeply grateful to the many people who participated in the development and tests of the biogeochemical profiler at Ifremer facilities in Brest (France) and during the N-ICE 2015 ice camp from RV Lance north of Svalbard: Magali Garracio, Antoine Guillot, Christine Drezen and Michel Calzas, Nicolas Villacieros Robineau, Jean-Philippe Savy, and Victoire Rérolle. We thank Matthieu Labaste, Victoire Rérolle, and Sergey Pisarev for their contribution to the preparation and deployment of the IAOOS platforms from the North Pole in April 2017. Magali Garracio was essential to the data recovery and decoding processes. Discussions with Catherine Schmechtig on the data processing are gratefully acknowledged.

The development and field work were funded through the ANR EQUIPEX IAOOS project through ANR-10-EQX-32-01 Grant and the ICE-ARC program from the European Union 7th framework program, Grant 603887. Elisabeth Boles, Zoe Koenig, and Marylou Athanase were supported through the Pan Arctic Options Belmont Forum project (ANR-14-AORS-003-01). Data used in this study can be found at this site (https://doi.org/10.17882/59183). continuously and across all seasons, is imperative. Drifting biogeochemical profilers like IAOOS 23 are unparalleled for the task. Additionally, this data set is instrumental for validating Earth system models and improving parametrization of the timing, location and regional limitations on under-ice primary production. Once validated, these models can be used to make more reliable predictions of both ecosystem dynamics and carbon cycling in the future Arctic environment.

\section{References}

Alling, V., Sanchez-Garcia, L., Porcelli, D., Pugach, S., Vonk, J. E., van Dongen, B., et al. (2010). Nonconservative behavior of dissolved organic carbon across the Laptev and East Siberian seas. Global Biogeochemical Cycles, 24, GB4033. https://doi.org/10.1029/ 2010GB003834

Arrigo, K. R., Perovich, D. K., Pickart, R. S., Brown, Z. W., van Dijken, G. L., Lowry, K. E., et al. (2012). Massive phytoplankton blooms under Arctic sea ice. Science, 336(6087), 1408. https://doi.org/10.1126/science.1215065

Arrigo, K. R., Perovich, D. K., Pickart, R. S., Brown, Z. W., van Dijken, G. L., Lowry, K. E., et al. (2014). Phytoplankton blooms beneath the sea ice in the Chukchi sea. Deep-Sea Research Part II: Topical Studies in Oceanography, 105, 1-16. https://doi.org/10.1016/j. dsr2.2014.03.018

Arrigo, K. R., \& van Dijken, G. L. (2015). Continued increases in Arctic Ocean primary production. Progress in Oceanography, 136, 60-70. https://doi.org/10.1016/j.pocean.2015.05.002

Assmy, P., Fernández-Méndez, M., Duarte, P., Meyer, A., Randelhoff, A., Mundy, C. J., et al. (2017). Leads in Arctic pack ice enable early phytoplankton blooms below snow-covered sea ice. Scientific Reports, 7(1), 40850. https://doi.org/10.1038/srep40850

Athanase, M., Sennéchael, N., Garric, G., Koenig, Z., Boles, E., \& Provost, C. (2019). New hydrographic measurements of the upper Arctic Western Eurasian Basin in 2017 reveal fresher mixed layer and shallower warm layer than 2005-2012 climatology. Journal of Geophysical Research: Oceans, 124, 1091-1114. https://doi.org/10.1029/2018JC014701

Berge, J., Geoffroy, M., Johnsen, G., Cottier, F., Bluhm, B., \& Vogedes, D. (2016). Ice-tethered observational platforms in the Arctic Ocean pack ice. IFAC-PapersOnLine, 49(23), 494-499. https://doi.org/10.1016/j.ifacol.2016.10.484

Bluhm, B. A., Kosobokova, K. N., \& Carmack, E. C. (2015). A tale of two basins: An integrated physical and biological perspective of the deep Arctic Ocean. Progress in Oceanography, 139, 89-121. https://doi.org/10.1016/j.pocean.2015.07.011

Boetius, A., Albrecht, S., Bakker, K., Bienhold, C., Felden, J., Fernández-Méndez, M., et al., \& RV Polarstern ARK27-3-Shipboard Science Party (2013). Export of algal biomass from the melting Arctic sea ice. Science, 339(6126), 1430-1432. https://doi.org/10.1126/ science. 1231346

Booth, B. C., \& Horner, R. A. (1997). Microalgae on the Arctic Ocean section, 1994: Species abundance and biomass. Deep-Sea Research Part II: Topical Studies in Oceanography., 44(8), 1607-1622. https://doi.org/10.1016/S0967-0645(97)00057-X

Brunet, C., Johnsen, G., Lavaud, J., \& Roy, S. (2011). Pigments and photoacclimation processes. In S. Roy, C. Llewellyn, E. Egeland, \& G. Johnsen (Eds.), Phytoplankton pigments: characterization, chemotaxonomy and applications in oceanography, Cambridge Environmental Chemistry Series (pp. 445-471). Cambridge: Cambridge University Press. https://doi.org/10.1017/ CBO9780511732263.017

Cetinić, I., Perry, M. J., D'Asaro, E., Briggs, N., Poulton, N., Sieracki, M. E., \& Lee, C. M. (2015). A simple optical index shows spatial and temporal heterogeneity in phytoplankton community composition during the 2008 North Atlantic bloom experiment. Biogeosciences, 12 , 2179-2194. https://doi.org/10.5194/bg-12-2179-2015

Codispoti, L. A., Kelly, V., Thessen, A., Matrai, P., Suttles, S., Hill, V., et al. (2013). Synthesis of primary production in the Arctic Ocean: III. Nitrate and phosphate based estimates of net community production. Progress in Oceanography, 110, 126-150. https://doi.org/10.1016/j. pocean.2012.11.006

Gonçalves-Araujo, R., Rabe, B., Peeken, I., \& Bracher, A. (2018). High colored dissolved organic matter (CDOM) absorption in surface waters of the central-eastern Arctic Ocean: Implications for biogeochemistry and ocean color algorithms. PLoS ONE, 13(1), e0190838. https://doi.org/https://doi.org/10.1371/journal.pone.0190838

Gosselin, M., Levasseur, M., Wheeler, P. A., Horner, R. A., \& Booth, B. C. (1997). New measurements of phytoplankton and ice algal production in the Arctic Ocean. Deep-Sea Research Part II: Topical Studies in Oceanography, 44(8), 1623-1625, 1627-1644. https://doi. org/10.1016/S0967-0645(97)00054-4

Granskog, M. A., Pavlov, A. K., Sagan, S., Kowalczuk, P., Raczkowska, A., \& Stedmon, C. A. (2015). Effect of sea-ice melt on inherent optical properties and vertical distribution of solar radiant heating in Arctic surface waters. Journal of Geophysical Research: Oceans, 120, 7028-7039. https://doi.org/10.1002/2015JC011087

Granskog, M. A., Stedmon, C. A., Dodd, P. A., Amon, R. M. W., Pavlov, A. K., De Steur, L., \& Hansen, E. (2012). Characteristics of colored dissolved organic matter (CDOM) in the Arctic outflow in the Fram Strait: Assessing the changes and fate of terrigenous CDOM in the Arctic Ocean. Journal of Geophysical Research, 117, C12021. https://doi.org/10.1029/2012JC008075

Hill, V. J., Light, B., Steele, M., \& Zimmerman, R. (2018). Light availability and phytoplankton growth beneath Arctic sea ice: Integrating observations and modeling. Journal of Geophysical Research: Oceans, 123, 3651-3667. https://doi.org/10.1029/2017JC013617

Jackson, K., Wilkinson, J., Maksym, T., Meldrum, D., Beckers, J., Haas, C., \& Mackenzie, D. (2013). A novel and low-cost sea ice mass balance buoy. Journal of Atmospheric and Oceanic Technology, 30, 2676-2688. https://doi.org/10.1175/JTECH-D-13-00058.1

Koenig, Z., Provost, C., Villacieros-Robineau, N., Sennéchael, N., \& Meyer, A. (2016). Winter ocean-ice interactions under thin sea ice observed by IAOOS platforms during N-ICE 2015: Salty surface mixed layer and active basal melt. Journal of Geophysical Research: Oceans, 121, 7898-7916. https://doi.org/10.1002/2016JC012195

Laney, S. R., Krishfield, R. A., \& Toole, J. M. (2017). The euphotic zone under Arctic Ocean sea ice: Vertical extents and seasonal trends. Limnology and Oceanography, 62, 1910-1934. https://doi.org/10.1002/lno.10543

Laney, S. R., Krishfield, R. A., Toole, J. M., Hammar, T. R., Ashjian, C. J., \& Timmermans, M. L. (2014). Assessing algal biomass and bio-optical distributions in perennially ice-covered polar ocean ecosystems. Polar Science, 8(2), 73-85. https://doi.org/10.1016/j. polar.2013.12.003

Letscher, R. T., Hansell, D. A., \& Kadko, D. (2011). Rapid removal of terrigenous dissolved organic carbon over the Eurasian shelves of the Arctic Ocean. Marine Chemistry, 123(1-4), 78-87. https://doi.org/10.1016/j.marchem.2010.10.002

Li, W. K. W., McLaughlin, F. A., Lovejoy, C., \& Carmack, E. C. (2009). Smallest algae thrive as the Arctic Ocean freshens. Science, 326(5952), 539. https://doi.org/10.1126/science.1179798 
Lind, S., Ingvaldsen, R. B., \& Furevik, T. (2018). Arctic warming hotspot in the northern Barents Sea linked to declining sea-ice import. Nature Climate Change, 8, 634-639. https://doi.org/10.1038/s41558-018-0205-y

Lovejoy, C. (2014). Changing views of Arctic protists (marine microbial eukaryotes) in a changing Arctic. Acta Protozoologica, 53(1), 91-100. https://doi.org/10.4467/16890027AP.14.009.1446

Lund-Hansen, L. C., Markager, S., Hancke, K., Stratmann, T., Rysgaard, S., Ramløv, H., \& Sorrell, B. K. (2015). Effects of sea-ice light attenuation and CDOM absorption in the water below the Eurasian sector of Central Arctic Ocean $\left(>88^{\circ} \mathrm{N}\right)$. Polar Research, 34(1), 23,978. https://doi.org/10.3402/polar.v34.23978

Mariage, V., Pelon, J., Blouzon, F., Victori, S., Geyskens, N., Amarouche, N., et al. (2017). IAOOS microlidar-on-buoy development and first atmospheric observations obtained during 2014 and 2015 arctic drifts. Optics Express, 25(4), A73-A84. https://doi.org/10.1364/ OE.25.000A73

Massicotte, P., Bécu, G., Lambert-Girard, S., Leymarie, E., \& Babin, M. (2018). Estimating underwater light regime under spatially heterogeneous sea ice in the Arctic. Applied Sciences. https://doi.org/10.3390/app8122693

Mayot, N., Matrai, P., Ellingsen, I. H., Steele, M., Jonhson, K., Riser, S. C., \& Swift, D. (2018). Assessing phytoplankton activities in the seasonal ice zone of the Greenland Sea over an annual cycle. Journal of Geophysical Research: Oceans, 123, 8004-8025. https://doi.org/ 10.1029/2018JC014271

Mundy, C. J., Gosselin, M., Ehn, J., Gratton, Y., Rossnagel, A., Barber, D. G., et al. (2009). Contribution of under-ice primary production to an ice-edge upwelling phytoplankton bloom in the Canadian Beaufort Sea. Geophysical Research Letters, 36, L17601. https://doi.org/ 10.1029/2009GL038837

Mundy, C. J., Gosselin, M., Gratton, Y., Brown, K., Galindo, V., Campbell, K., et al. (2014). Role of environmental factors on phytoplankton bloom initiation under landfast sea ice in resolute passage, Canada. Marine Ecology Progress Series, 497, 39-49. https://doi.org/10.3354/ meps10587

Nencioli, F., Chang, G., Twardowski, M., \& Dickey, T. D. (2010). Optical characterization of an eddy-induced diatom bloom west of the island of Hawaii. Biogeosciences, 7, 151-162. https://doi.org/10.5194/bg-7-151-2010

Olli, K., Wassmann, P., Reigstad, M., Ratkova, T. N., Arashkevich, E., Pasternak, A., et al. (2007). The fate of production in the central Arctic Ocean-Top-down regulation by zooplankton expatriates? Progress in Oceanography, 72(1), 84-113. https://doi.org/10.1016/j. pocean.2006.08.002

Palmer, M. A., Arrigo, K. R., Mundy, C. J., Ehn, J. K., Gosselin, M., Barber, D. G., et al. (2011). Spatial and temporal variation of photosynthetic parameters in natural phytoplankton assemblages in the Beaufort Sea, Canadian Arctic. Polar Biology, 34(12), $1915-1928$. https://doi.org/10.1007/s00300-011-1050-x

Para, J., Charrière, B., Matsuoka, A., Miller, W. L., Rontani, J. F., \& Sempéré, R. (2013). UV/PAR radiation and DOM properties in surface coastal waters of the Canadian shelf of the Beaufort Sea during summer 2009. Biogeosciences, 10, 2761-2774. https://doi.org/10.5194/ bg-10-2761-2013

Pavlov, A. K., Granskog, M. A., Stedmon, C. A., Ivanov, B. V., Hudson, S. R., \& Falk-Petersen, S. (2015). Contrasting optical properties of surface waters across the Fram Strait and its potential biological implications. Journal of Marine Systems, 143, 62-72. https://doi.org/ 10.1016/j.jmarsys.2014.11.001

Perovich, D., Meier, W., Tschudi, M., Farrell, S., Hendricks, S., Gerland, S., et al. (2018). Sea Ice [in Arctic Report Card 2018], https://www. arctic.noaa.gov/Report-Card

Polyakov, I. V., Pnyushkov, A. V., Alkire, M. B., Ashik, I. M., Baumann, T. M., Carmack, E. C., et al. (2017). Greater role for Atlantic inflows on sea-ice loss in the Eurasian Basin of the Arctic Ocean. Science, 356(6335), 285-291. https://doi.org/10.1126/science.aai8204

Provost, C., Sennéchael, N., Garçon, V., Boles, E., Athanase, M., Koenig, Z., Labaste, M. (2017). Arctic Western Eurasian basin: IAOOS 23 physical and biogeochemical profiles in 2017. SEANOE. https://doi.org/10.17882/59183

Randelhoff, A., \& Guthrie, J. D. (2016). Regional patterns in current and future export production in the central Arctic Ocean quantified from nitrate fluxes. Geophysical Research Letters, 43, 8600-8608. https://doi.org/10.1002/2016GL070252

Randelhoff, A., Reigstad, M., Chierici, M., Sundfjord, A., Ivanov, V., Cape, M., et al. (2018). Seasonality of the physical and biogeochemical hydrography in the inflow to the Arctic Ocean through Fram Strait. Frontiers in Marine Science, 5, 224. https://doi.org/10.3389/ fmars.2018.00224

Rich, J., Gosselin, M., Sheer, E., Sheer, B., \& Kirchman, D. L. (1997). High bacterial production, uptake and concentrations of dissolved organic matter in the central Arctic Ocean. Deep Sea Research Part II: Topical Studies in Oceanography, 44(8), 1645-1663. https://doi.org/ 10.1016/S0967-0645(97)00058-1

Sanders, R. W., \& Gast, R. J. (2012). Bacterivory by phototrophic picoplankton and nanoplankton in Arctic waters. FEMS Microbiology Ecology, 82(2), 242-253. https://doi.org/10.1111/j.1574-6941.2011.01253

Slagstad, D., Wassmann, P. F. J., \& Ellingsen, I. (2015). Physical constrains and productivity in the future Arctic Ocean. Frontiers in Marine Science, 2. https://doi.org/10.3389/fmars.2015.00085

Stedmon, C. A., Amon, R. M. W., Rinehart, A. J., \& Walker, S. A. (2011). The supply and characteristics of colored dissolved organic matter (CDOM) in the Arctic Ocean: Pan Arctic trends and differences. Marine Chemistry, 124(1-4), 108-118. https://doi.org/10.1016/j. marchem.2010.12.007

Stoecker, D. K., Hansen, P. J., Caron, D. A., \& Mitra, A. (2017). Mixotrophy in the marine plankton. Annual Review of Marine Science, 9 , 311-335. https://doi.org/10.1146/annurev-marine-010816-060617

Strass, V. H., \& Nöthig, E. M. (1996). Seasonal shifts in ice edge phytoplankton blooms in the Barents Sea related to the water column stability. Polar Biology, 16(6), 409-422. https://doi.org/10.1007/BF02390423

Våge, K., Pickart, R. S., Pavlov, V., Lin, P., Torres, D. J., Ingvaldsen, R., et al. (2016). The Atlantic water boundary current in the Nansen Basin: Transport and mechanisms of lateral exchange. Journal of Geophysical Research: Oceans, 121, 6946-6960. https://doi.org/10.1002/ 2016JC011715

Vancoppenolle, M., Bopp, L., Madec, G., Dunne, J., Ilyina, T., Halloran, P. R., \& Steiner, N. (2013). Future arctic ocean primary productivity from CMIP5 simulations: Uncertain outcome, but consistent mechanisms. Global Biogeochemical Cycles, 27, 605-619. https://doi.org/ $10.1002 /$ gbc. 20055

Zhao, M., Timmermans, M. L., Cole, S., Krishfield, R., Proshutinsky, A., \& Toole, J. (2014). Characterizing the eddy field in the Arctic Ocean halocline. Journal of Geophysical Research: Oceans, 119, 8800-8817. https://doi.org/10.1002/2014JC010488 